\title{
Role of Infection and Immunity in Bovine Perinatal Mortality: Part 1. Causes and Current Diagnostic Approaches
}

\author{
John F. Mee ${ }^{1, *}$, Paulina Jawor ${ }^{2}$ (D) and Tadeusz Stefaniak ${ }^{2} \mathbb{D}$ \\ 1 Animal and Bioscience Research Department, Teagasc, Moorepark Research Centre, \\ P61 P302 Fermoy, County Cork, Ireland \\ 2 Department of Immunology, Pathophysiology and Veterinary Preventive Medicine, Wrocław University of \\ Environmental and Life Sciences, 50-375 Wrocław, Poland; paulina.jawor@upwr.edu.pl (P.J.); \\ tadeusz.stefaniak@upwr.edu.pl (T.S.) \\ * Correspondence: john.mee@teagasc.ie
}

check for updates

Citation: Mee, J.F.; Jawor, P.; Stefaniak, T. Role of Infection and Immunity in Bovine Perinatal Mortality: Part 1. Causes and Current Diagnostic Approaches. Animals 2021, 11, 1033. https://doi.org/10.3390/ ani11041033

Academic Editor: Emma Bleach

Received: 11 January 2021

Accepted: 24 March 2021

Published: 6 April 2021

Publisher's Note: MDPI stays neutral with regard to jurisdictional claims in published maps and institutional affiliations.

Copyright: (c) 2021 by the authors. Licensee MDPI, Basel, Switzerland. This article is an open access article distributed under the terms and conditions of the Creative Commons Attribution (CC BY) license (https:// creativecommons.org/licenses/by/ $4.0 /)$.
Simple Summary: Death of calves before, during and up to $48 \mathrm{~h}$ after birth is referred to as bovine perinatal mortality (PM). This is caused mainly by calving problems. However, some cases of PM are caused by infections (pathogenic microbes). Infections include bacteria, viruses, parasites and fungi, and in some cases, multiple pathogens. Diagnosis of infection as a cause of PM can be difficult as one needs to differentiate between exposure to the pathogen, infection by the pathogen and the pathogen causing PM. Most cases of PM attributed to infection are caused by infections acquired in utero. Investigation of infectious PM involves collecting a health history of the dam, the calf and their herd, post-mortem examination of the dead calf and its placenta and collecting appropriate samples for laboratory testing.

\begin{abstract}
While non-infectious causes are more commonly diagnosed in cases of bovine perinatal mortality (PM), the proportion caused by infections is highly variable between studies ( 5-35\%); the reasons for this variation, and possible underestimation, are discussed. The most important pathogenspecific infectious causes of PM are bacteria (in particular, Bacillus licheniformis and Leptospira spp.), viruses (in particular BVDv) and a parasite (Neospora caninum). However, co-infection may occur in a small proportion of cases and in many cases no single pathogen is detected but gross or microscopic lesions of an inflammatory response are identified. Diagnosis is complicated by the criteria required to establish exposure, infection and causation. Additionally, pathogens can be classified as primary or secondary though such differentiation can be arbitrary. The majority of infectious cases of PM are due to in utero infections but postnatal infections (0-2 days) can also cause PM. Diagnosis of infectious PM is based on a systematic investigation of the herd health history and dam and cohort sampling and examination of the perinate and its placenta. Gross and histopathologic examinations and maternal/herd and perinate serology form the basis of current infectious PM investigations.
\end{abstract}

Keywords: primary and secondary pathogens; Neospora: BVDv; Bacillus: Leptospira; perinatal mortality; stillbirth; necropsy; foetus; placenta

\section{Introduction}

Perinatal mortality (PM) may be defined as the death of a fullterm ( $\geq 260$ day) foetus or perinate which dies within $48 \mathrm{~h}$ of birth. To be clear, PM encompasses deaths which occur in utero, during parturition and postnatally, hence the descriptor 'perinatal' meaning around birth. The term postnatal, as used in this manuscript, means within two days of birth. It is an international animal health and welfare issue [1]. Broadly speaking, the causes of PM may be classified as infectious and non-infectious. Non-infectious causes, in particular dystocia (abnormal calving) and asphyxia, are more common than infectious causes (Table 1). In general, infectious causes account for approximately 15\% of PM cases, varying widely between studies ( 5-35\%), (Table 1$)$. Infection commonly ranks as the 
second or third most common diagnosed cause of PM. However, these data originate in studies where not all calves/organs/tissues are sampled and where the number of pathogens tested for is variable. Thus, it is probable that all studies underestimate the role of infection in PM of calves.

The aims of this review are, to present the state-of-the-art in published knowledge on the infectious causes of bovine PM globally and the current methods of diagnosis. While reference is made to both abortions (termination of gestation prior to $260 \mathrm{~d}$ of gestation) and neonatal mortality (calf death after two days of age) where necessary, the focus of this review is on the perinatal period as defined above.

\section{Infectious Causes of Perinatal Mortality}

This section will deal with three aspects of the infectious causes of perinatal mortality: the basic principles underlying such infections, the pathogens causing these infections and the current methods of diagnosis of these pathogens as causes of perinatal mortality. Novel, future diagnostics as well as response to infections are discussed by Jawor et al., [2] in Part 2 of this mini-series.

\subsection{Principles of Perinatal Infections}

Before discussing the individual pathogens and their diagnosis, it is necessary to discuss more basic but equally important aspects of the relationship between the pathogen and the host. These include the types of infectious agents, the occurrence of co-infections, the principles of primary and secondary infections, the profile of in utero versus postnatal (0-2 days) infections, the concepts of exposure, infection and causality, the 'role' of infection in PM, the proportion of PM caused by infection and finally, the infectious agents causally linked to perinatal mortality.

\subsubsection{Types of Infectious Agents}

Bacteria, viruses, parasites and fungi are known to cause PM in calves. Bacterial infections are the most common type of pathogen infection in PM calves, though this can vary widely between studies. For example, studies in the UK [3], Poland [4] and in Denmark [5] reported a low prevalence of stomach content-culture positives in stillborn calves $-2,<2$ and $0.8 \%$, respectively. However, a much higher percentage of culture positives were recorded in a Finnish study [6] where a significant bacterial isolation was made in $10 \%$ of calves which died within $24 \mathrm{~h}$ of birth. Some viruses are relatively commonly detected in PM calves (e.g., BVDv), e.g., [7] and on occasion, in epidemics, viruses may be even more commonly detected, e.g., the emergence of novel viruses, for instance, Schmallenberg virus [8]. While most parasites are not detected in PM calves, one particular protozoal parasite, Neospora caninum, is the most common pathogen detected in many bovine PM studies $[4,9,10]$. Fungi are detected in PM calves at a very low rate though they are detected more frequently in studies where both aborted foeti and perinates are combined [11,12]. Thus, bacterial, viral and neospora infections are the most frequently diagnosed types of infections in PM calves.

However, in many cases of PM infection a single (or multiple pathogen) is not detected (or detectable, e.g., autolysis, contaminated, scavenged carcass or incorrect/inadequate sampling, especially absence of the placenta) but compelling gross or microscopic lesions indicative of inflammatory response to a pathogen is detected $[13,14]$. Thus, describing foetopathogens exclusively does not adequately describe the 'picture' of PM infections.

The data in Table 1 refer to both detection of pathogens and of lesions indicative of an inflammatory response to pathogens. 
Table 1. Necropsy-diagnosed causes-of-death (\%) for calves dying in the perinatal period $(0-48 \mathrm{~h})$ internationally.

\begin{tabular}{|c|c|c|c|c|c|c|c|c|c|c|}
\hline Country & Perinate Definition & Calves (No.) & Calf Type & Dystocia & Anoxia & Congenital Defects & Infection & Other & Unknown & Reference \\
\hline Argentina & Gestation $>260 \mathrm{~d}$-stillborn & 19 & Dairy & 21.1 & $\mathrm{NR}^{1}$ & NR & 10.6 & 5.3 & 68.4 & [9] \\
\hline Belgium & Gestation fullterm-died $\leq 24 \mathrm{~h}$ & NR & Dairy \& Beef & 7 & 55 & 6 & 18 & 4 & 10 & [15] \\
\hline Denmark & Stillbirth & 130 & Dairy \& Beef & 9 & 81 & 1.5 & 8 & 0.1 & 0 & [5] \\
\hline Finland & Gestation fullterm—died $\leq 24 \mathrm{~h}$ & 148 & Dairy & 43 & $\mathrm{NR}^{2}$ & 10 & 14 & 8 & 25 & [6] \\
\hline Iceland & Gestation fullterm-died $\leq 24 \mathrm{~h}$ & 129 & Dairy & 34 & 37 & NR & 12 & 13 & 3.9 & [16] \\
\hline Ireland & Gestation $\geq 260 \mathrm{~d}$-died $\leq 48 \mathrm{~h}$ & 1345 & Dairy & 33 & 10 & 11 & 9 & 28 & 9 & [10] \\
\hline Japan & Stillbirth & 155 & Beef & 21 & NR & 3.9 & NR & 5.1 & 69.7 & [17] \\
\hline Netherlands & Stillbirth & 193 & Dairy & 4 & 37 & 8.3 & 7.3 & 6 & 42 & [18] \\
\hline Nr. Ireland & Gestation fullterm-died $\leq 10 \mathrm{~min}$. & 365 & Dairy & 23 & 46 & NR & 31 & NR & NR & [19] \\
\hline Poland & Gestation fullterm-died $\leq 6 \mathrm{~h}$ & 121 & Dairy & NR & NR & NR & 9.9 & NR & NR & [4] \\
\hline Scotland & Gestation fullterm-died $\leq 48 \mathrm{~h}$ & 54 & Beef & $37^{2}$ & NR & 11.1 & 35.2 & 3.7 & 13.0 & [14] \\
\hline Sweden & Gestation fullterm—died $\leq 24 \mathrm{~h}$ & 76 & Dairy & 46.1 & NR & 5.3 & 2.6 & 10.5 & 35.5 & [20] \\
\hline USA & Gestation fullterm-died $\leq 48 \mathrm{~h}$ & 60 & Dairy & 25 & 28.5 & 3.3 & 5 & 6.6 & 31.6 & [22] \\
\hline
\end{tabular}

${ }^{1} \mathrm{NR}=$ not recorded, ${ }^{2}$ anoxic and dystocic lesions combined, ${ }^{3}$ Ultimate cause of death (COD). 


\subsubsection{Co-Infection}

Although in the majority of infections, a single pathogen is detected, dual infection in a single calf is not uncommon $[21,23,24]$, but reports of multiple co-infections, particularly in multiple foetuses, are uncommon [25]. Diagnosis of multiple infections, after excluding opportunistic agents, suggests a high environmental infectious challenge. This may occur where a common pathogen is endemic in a herd, e.g., $N$ caninum or Coxiella burnettii and infected calves are co-infected with other/another, often sporadic, pathogen [4,21].

\subsubsection{Primary and Secondary Pathogens}

Primary pathogens are capable of crossing the intact placenta and causing placentitis [26], foetopathy [27] or luteal regression [28] due to their intrinsic virulence in healthy cows and so often require a low infective dose. Primary pathogens are often associated with outbreaks of PM. An extensive list of examples is shown in Table 2.

Table 2. List of primary and secondary pathogens associated with bovine foetopathy in alphabetical order*.

\begin{tabular}{|c|c|}
\hline Primary & Secondary \\
\hline Akabane virus & Absidia spp. \\
\hline Anaplasma phagocytophilium & Arcobacteria spp. \\
\hline Aspergillus spp. & Acinetobacter species \\
\hline Bluetongue virus & Actinomyces spp. \\
\hline Brucella abortus & Aerococcus spp. \\
\hline Bovine adenovirus 5 & Aeromonas hydrophila \\
\hline Bovine herpes viruses 1 and 4 & Bacillus spp. \\
\hline Bovine viral diarrhoea virus & $\begin{array}{l}\text { Chlamydia-related organisms (CRO), e.g., } \\
\text { Parachlamydia-like organisms (PCO), Waddlia spp. }\end{array}$ \\
\hline Bacillus licheniformis & Citrobacter youngae \\
\hline Campylobacter foetus spp. & Escherichia spp. \\
\hline Chlamydophila abortus & Fusobacterium spp \\
\hline Clostridium perfringens & Hafnia alvei \\
\hline Coxiella burntiii & Histophilus somni \\
\hline Leptospira spp. & Klebsiella pneumonia \\
\hline Listeria monocytogenes & Listeria spp. \\
\hline Mycoplasma spp. & Mannheimia spp. \\
\hline Neospora caninum & Neisseria, \\
\hline Parainfluenza 3 virus & Nocardia spp. \\
\hline Salmonella spp. & Pantoea agglomerans \\
\hline Schmallenberg virus & Pasteurella spp. \\
\hline Trichomonas foetus foetus & Providencia stuartii \\
\hline \multirow[t]{6}{*}{ Trueperella pyogenes } & Serratia spp. \\
\hline & Staphylococcus spp. \\
\hline & Streptococcus spp. \\
\hline & Ureaplasma spp. \\
\hline & Yeasts \\
\hline & Yersinia spp. \\
\hline
\end{tabular}

* Readers are referred to standard veterinary microbiology textbooks for further information on these microbes. 
Secondary or opportunistic pathogens (now termed pathobionts or facultative pathogens or in some cases, opportunistic emerging pathogens-[29]) are incapable of transplacental infection unless the placenta is damaged, the microflora in the reproductive tract is altered (dysbiosis) or the cow is immuno-compromised (e.g., by prior BVDv infection). Examples are listed in Table 2. They can infect the foeto-placentum once the cervix is open (ascending infection) or from the pregnant cow's bowel or lungs or a focus of infection, e.g., abscess (haematogenous infection). While these opportunistic agents are usually not considered a primary cause of foetopathy, if they induce a bacteraemia or septicaemic or auto-immune response, or exacerbate a co-infection, they may result in PM [30]. Hence, their isolation is often reported by laboratories as of 'uncertain significance'. These organisms are part of the normal microbiome of the host and its environment (e.g., poorly preserved forage) and tend not to be contagious. Secondary pathogens are usually associated with sporadic PM [29].

While the lists compiled in Table 2 are generally accepted [3,29,31-34], they are not unanimously agreed. For example, the following organisms are considered secondary, not primary pathogens by some authors: Bacillus licheniformis [35], Listeria monocytogenes [3,36], Salmonella Dublin [3], Trueperella pyogenes $[3,33,36]$ while Ureaplasma spp are considered primary, not secondary pathogens by Anderson [31].

Irrespective of whether a pathogen is considered primary or secondary, in order for it to be considered the cause of PM three criteria need to be satisfied: the pathogen is found in heavy or pure growth in the abomasum and/or other tissues, there is an associated inflammatory process in the foetal tissues and/or placenta and other causes of PM can be excluded. The third criterion is important where infection may be a co-morbidity but not the cause of death. For example, where the first two criteria are fulfilled but there is a compelling co-existing cause of death-infection in a calf which suffers a fractured spine during traumotocia. In this case the calf is infected but the probable cause of death is trauma, not infection, though a diagnosis of co-mortality; infection and traumotocia may yield a richer profile of the circumstances surrounding the calf's death.

\subsubsection{Infectious Agents Linked to Perinatal Mortality}

The pathogens most commonly detected in perinatal mortality studies are Neospora caninum and viruses (e.g., BVD), followed by Bacillus spp and Leptospira, and, to a much lesser extent, other bacteria and fungi (Table 3). The proportion of infections (not cases of PM) attributed to each of these pathogens varies widely between studies (2-100\%) primarily due to the limited number of cases detected with infectious agents in many studies. Only three pathogens (Neospora caninum [4], viruses (BVD) [22] and Bacillus spp. [14]) have been detected in $50 \%$ or more of infected perinatal mortality cases where a pathogen is recorded. However, given the low proportion of all-cause PM attributed to infection or where infection is detected, individual pathogens are rarely detected in more than $10 \%$ of PM cases. The pathogens outlined, alphabetically, hereunder have been most frequently linked to PM in calves. This is not an exhaustive list; see Table 2 and veterinary textbooks for further details.

\section{Bacillus licheniformis}

Bacillus licheniformis has been detected in $\sim 5 \%$ of PM calves, generally in the abomasal contents, e.g., 2 and $0.8 \%$, in studies in the UK [37] and Denmark [5], respectively. It is more commonly detected in suckler than dairy foetuses [38]. It can be more common in high risk environments, e.g., housed beef cows fed pit grass silage [39] and can cause serious loss in co-infections, e.g., BVDv [40]. Bacillus infection (haematogenous) typically causes necrotizing placentitis, bronchopneumonia and pericarditis, (Figure 1), [26]. Common risk factors are housed cattle offered mouldy or spoiled forage. 
Table 3. Distribution of pathogens (antigens) detected in calves dying in the perinatal period $(0-48 \mathrm{~h})$ internationally (\% of dead perinates).

\begin{tabular}{|c|c|c|c|c|c|c|c|c|c|c|c|c|c|}
\hline Country & Infected Calves (No.) & Infection(\%) & Bac. lich. & Cox. burn. & Fungi & Lepto. spp. & List. spp. & Neo. cani. & Tru. pyog. & Salm. spp. & Viruses & Other inf. & Reference \\
\hline Argentina & 19 & 10.6 & NR & NR & NR & NR & NR & 5.3 & NR & NR & NR & 5.3 & [9] \\
\hline Belgium & NR & 18 & NR & NR & NR & NR & NR & NR & NR & NR & 12 & 6 & [15] \\
\hline Canada & 560 & 4.3 & NR & NR & NR & NR & 0.4 & 0.2 & NR & NR & 0.2 & 3.5 & [13] \\
\hline Denmark & 130 & 8 & 1 & NR & NR & NR & NR & NR & NR & NR & 7 & NR & [5] \\
\hline Finland & 148 & 14 & 5 & NR & NR & NR & NR & 2 & 0.7 & NR & NR & 6.3 & [6] \\
\hline Iceland & 129 & 12 & NR & NR & NR & NR & NR & NR & NR & NR & NR & 12 & [16] \\
\hline Netherlands & 193 & 7.3 & 1.6 & NR & NR & NR & NR & NR & NR & 1.6 & 4.1 & NR & [18] \\
\hline Nr. Ireland & 365 & 31 & NR & NR & NR & 13.4 & NR & NR & NR & NR & NR & 17.6 & [19] \\
\hline Poland & 121 & 9.9 & NR & NR & NR & NR & NR & 7.4 & NR & NR & NR & 1.7 & [4] \\
\hline Scotland & 54 & 35.2 & 5.5 & NR & 3.7 & 1.9 & NR & NR & NR & NR & NR & 24.1 & [14] \\
\hline Sweden & 76 & 2.6 & NR & NR & NR & NR & NR & NR & NR & NR & NR & 2.6 & [20] \\
\hline Switzerland & 47 & 77 & NR & 31.9 & 8.5 & 6.4 & NR & 2.1 & NR & NR & NR & 28.1 & [21] \\
\hline USA & 60 & 5 & NR & NR & NR & NR & NR & NR & NR & NR & 5 & NR & [22] \\
\hline
\end{tabular}

Co-infections are listed under 'Other infection', NR-not reported. 


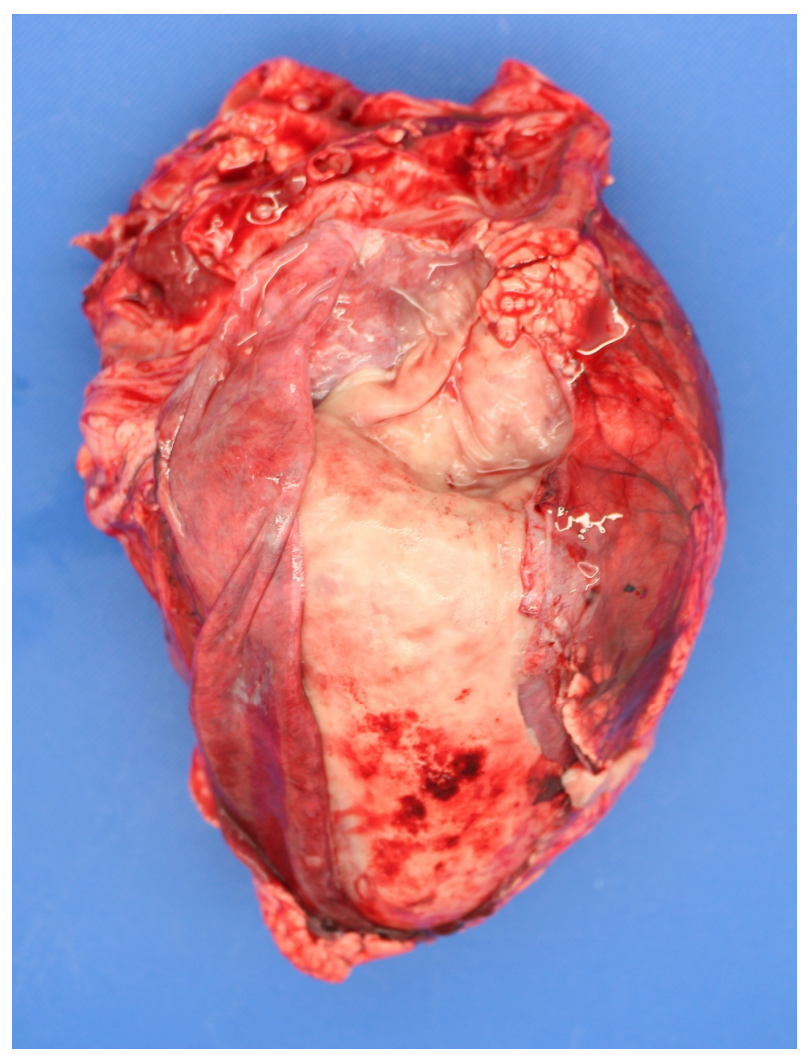

Figure 1. Extensive fibrinous pericarditis in a perinate infected with Bacillus licheniformis.

Bovine Viral Diarrhoea Virus (BVDv)

Bovine viral diarrhoea virus has generally been detected in $<10 \%$ of PM cases. However, the virus can also cause serious outbreaks of PM [7] and was one of the original pathogens associated with 'weak calf syndrome' [41]. It is more commonly detected in suckler than dairy foetuses [38]. Virus detection rate is dependent upon diagnostic technique; antigen-detection ELISA or RT-PCR being better than IFAT, virus isolation or serology [42]. Given the low (generally <1\%) prevalence of BVDv-persistently infected (PI) newborn calves internationally, unless a large number of PM calves are tested for virus it is likely that a false negative conclusion will arrived at regarding the presence of BVDV in such calves. For example, for every eight seropositive pre-colostral calves on commercial dairy farms in the USA, one PI was born [43]. However, BVDv can be detected in PM cases, e.g., in the study by Smyth et al. [23] where BVDv antigen was detected in $0.7 \%$ of PM calves. Similarly, the BVDv seroprevalence in newborn calves is low, e.g., 3.3\% of PM calves in a recent Polish study [4]. This indicates that infection occurred in the later stage of pregnancy, after 125 days of gestation [44].

\section{Leptospira spp.}

Leptospira serovar hardjo has generally been detected in $<10 \%$ of PM cases. The prevalence of pathogenic leptospira in PM calves may be determined by cattle population infection rates and related, use of leptospira vaccines. Hence, detection rates vary widely between countries, e.g., 3.3\% PCR-positive PM cases in a recent Polish study [4] compared to $14-26 \%$ fluorescent antibody test (FAT) positive PM cases in earlier studies in Northern Ireland $[23,45]$. Unlike many other bacteria which are easy to culture, leptospira are difficult to detect in PM calves (e.g., the FAT to detect leptospira requires a specialized laboratory with highly skilled staff and so is being replaced by PCR, e.g., [25]. Hence, evidence of foetal exposure (foetal antibodies) is often used as a surrogate indicator of foetal infection. However, detection of low foetal titres to Leptospira sp. (1:100-1:200) does not exclude the involvement of these bacteria in PM. Calves experimentally infected during pregnancy 
with Leptospira serovar hardjo which had different outcomes (apparently viable, weak, dead) varied in the extent of their immune response (microagglutination titres from undetectable to $1: 30,000$ in precolostral sera) [46]. Other non-maintenance leptospira species (e.g., L. Grippotyphosa and L. Australis) have been detected in jaundiced aborted and term bovine foetuses [47].

\section{Neospora caninum}

This parasite is commonly the most frequently detected pathogen in aborted calves (e.g., 18\% in Scotland, [48] and in PM calves but infection rates are generally lower $(<10 \%)$ in the latter. Neospora caninum is more commonly detected in dairy than suckler foetuses [38].Seropositive heifers are four-times more likely to have a PM case at first or second calving [49] and co-infection with BVDv may exacerbate this effect [50]. The percentage of PM calves with a positive humoral response (e.g., titre $\geq 1 / 320$ ) to $N$. caninum is about 5\% (4.1\% in Poland [4], 5.5\% in Northern Ireland, [51]. The timing of foetal infection with $N$. caninum determines the outcome of the pregnancy. Infection in late pregnancy allows the fetus to suppress infection and pregnancy ends in time for clinically normal calves to be born [52]. The highest rate of detection the N. caninum is in the brain, though the latter may be grossly normal. This may be because the parasite has a predilection for the central nervous system [53]. The occurrence of cell destruction, and therefore disease, depends upon the balance between tachyzoites being able to penetrate and multiply in host cells and the ability of the host to inhibit parasite multiplication [53].

\subsubsection{Infectious Agents Less Commonly Causally Linked to Perinatal Mortality}

Numerous less common pathogens have been detected in cases of PM, in crosssectional and longitudinal studies or often in case studies.

\section{Bovine Herpes Viruses}

Diagnosis of BoHV-1 and -4-associated PM is complicated by two factors. Firstly, this virus acts immunosuppressively, so foetuses whose dams were experimentally infected mount no antibody response although virus was detected in all organs (lungs, liver, spleen, kidneys, intestines, mesenteric lymph nodes) [54,55]. Secondly, many herds are vaccinated against BoHV-I and this may impact the detection rate in PM cases, e.g., in almost 30\% of Polish herds cows were vaccinated against BoHV-1, which could partly explain the failure to detect BoHV-1 in PM cases from these herds [4]. Additionally, as it has been shown that BoHV-1 challenge of vaccinated cows resulted in the birth of normal calves in which BoHV-1 virus was not isolated [56]. However, in field outbreaks both abortion and PM have occurred despite vaccination [57]. Even in studies when vaccination was not widespread, the virus has rarely been detected in large scale studies of PM, e.g., in none of 293 PM cases examined by Smyth et al. [23] although it has been detected in small PM case series [55] and reported to be involved in individual outbreaks of stillbirth, e.g., [58] and experimental inoculation studies have resulted in PM [59].

\section{Chlamydia and Chlamydia-Like Organisms}

While Chlamydia abortus is a recognised cause of bovine foetopathy [60] the role of Chlamydia-like organisms, e.g., Parachlamydia spp, in the aetiology of bovine abortion and $\mathrm{PM}$ is unclear. For example, attempts to experimentally induce abortion with a Waddlia chondrophilia inoculum failed [61]. Three studies described a possible association with bovine abortions $[60,62,63]$ but not PM. Even when detected in PM cases there may not always be associated lesions, e.g., in a recent Swiss study of the five cases of PM where these organisms were detected, three cases had inflammatory lesions (placentitis, alveolitis), while two cases were histologically normal [21]. Previous reports of PM cases in which C. abortus was diagnosed (by IHC) also reported placentitis [64]. 


\section{Coxiella burnetii}

Coxiella burnetii is not commonly detected in PM studies as it has a tropism for the placenta which is often not submitted and it is not generally tested for in the foetus. However, at the herd-level, the risk of stillborn calves and perinatal death can be higher with high level of BTM antibodies [65]. While high infection rates with C. burnetii can be detected in PM calves (e.g., 32\% of calves qPCR-positive in a recent Swiss study [21]), placental infection rate (15\% [21]) and evidence of inflammatory response (placentitis and bronchopneumonia) may be much lower (e.g., 19\% [21]). These findings suggest that acute infections with Coxiella burnetii, may occur without histological lesions. Foetoplacental infection rates reflect the infection rate in the at-risk cattle population which vary between countries based on serological surveys, e.g., $18 \%$ in Korea [66] compared to $38 \%$ in Ireland [67]. Foetal coxiellaemia associated with PM occurs sporadically in endemically infected herds and is more common in primiparae [68].

\section{Escherichia coli}

While this is one of the most common bacteria isolated from stillborn and aborted calves $[6,11]$, the significance of such infection is unclear; it may be an opportunist infection, a co-infection or a contaminant. One possible source of this pathogen could be an ascending infection in the reproductive tract. E coli is as commonly detected in suckler as in dairy foetuses [38]. Escherichia coli is also a common cause of postnatal (0-2 days) infectious PM-colisepticaemia [69].

\section{Fungi and Yeasts}

Aspergillus fumigatus, primarily [70] but also, Asp. niger, Mucor spp. and associated fungi and yeasts (e.g., Candida) are sporadically detected in PM studies, usually at a low rate $(<10 \%)$. Sporadic cases predominantly occur during the winter when pregnant cows are fed on conserved mouldy forage containing saprophytic fungi [70]. In a minority of cases foetal fungal dermal plaques or a thickened placenta may be observed [70].

\section{Listeria monocytogenes}

Listeria monocytogenes is not commonly detected in PM studies. It is more commonly detected in suckler than dairy foetuses [38]. As listeria spp. are soil-borne microbes they can cause infection when soil is incorporated with grass in silage pits without adequate anaerobic conditions during fermentation [71]. Both abortion and PM can result due to placentitis and foetal septicaemia with fine hepatic necrotic multifoci (sawdust liver) observed in some cases and occasionally associated hepatic rupture (Figure 2).

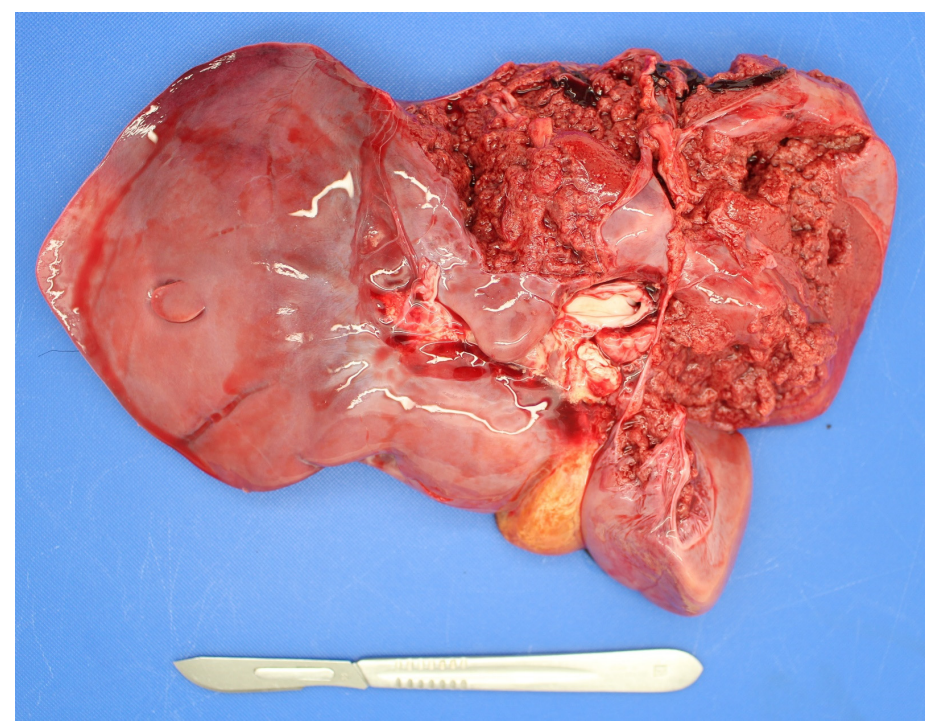

Figure 2. Hepatic rupture in a foetus infected with Listeria monocytogenes. 


\section{Mycoplasma Species}

Mycoplasma spp. are rarely tested for and when they are, are rarely detected in PM studies, e.g., none of 121 PM cases yielded mycoplasma spp. though a small percentage of dams (5\%) was seropositive [72]. They are occasionally detected in aborted foetuses [73-75] and experimental inoculum studies have resulted in abortion indicating they are primary pathogens [76,77].

\section{Salmonella Species}

Salmonella species are not commonly detected in PM studies being more commonly detected in aborted foetuses [78] and associated with neonatal calf mortality [79]. The most commonly detected Salmonella species is S. Dublin [78]. Infected foetuses are often autolysed (Figure 3). S. Dublin is more commonly detected in dairy than in suckler foetuses [38]. However, other species, e.g., S. Stanley, have also been detected in cases of PM [27].

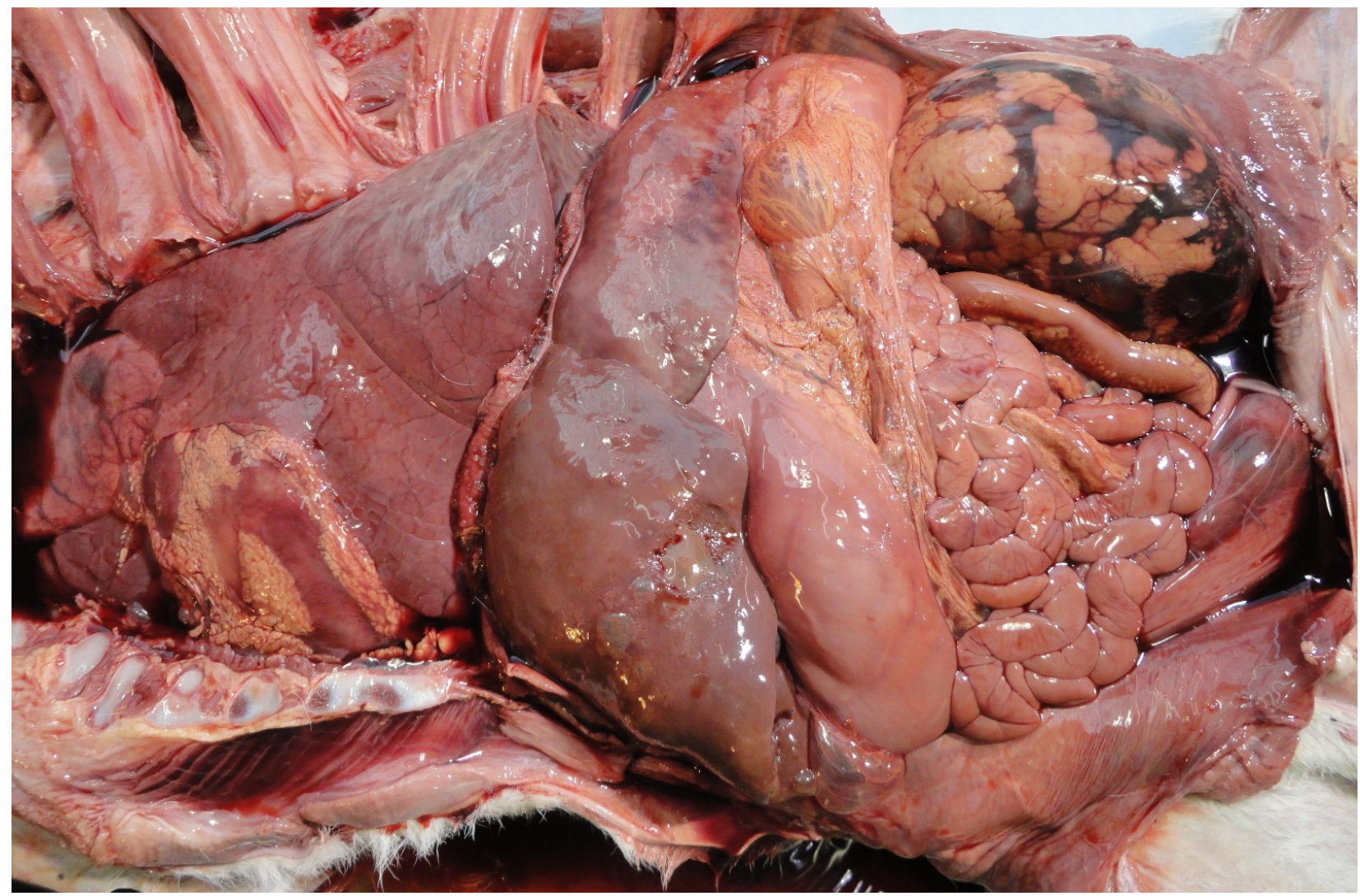

Figure 3. Autolysed foetus infected with Salmonella Dublin.

Schmallenberg Virus (SBV)

This virus was first detected in cattle in 2011 and despite re-occurrences since then, it has not become a common cause of bovine foetopathy except in virus recirculation years/regions due to protective seroprevalence endemicity [8]. However, younger, naïve, populations of susceptible cattle do present the potential for future cyclic outbreaks and PM in calves. The presence of SBV antibodies in PM calves without the pathognomonic gross malformations (AHS-arthrogryposis, hydranencephaly syndrome), (Figure 4a,b), suggests infection after 47 days of gestation when the foetus is immunocompetent [8]. Most fetuses infected after immunocompetence are born alive and seropositive but without lesions indicative of SBV infection [80]. 


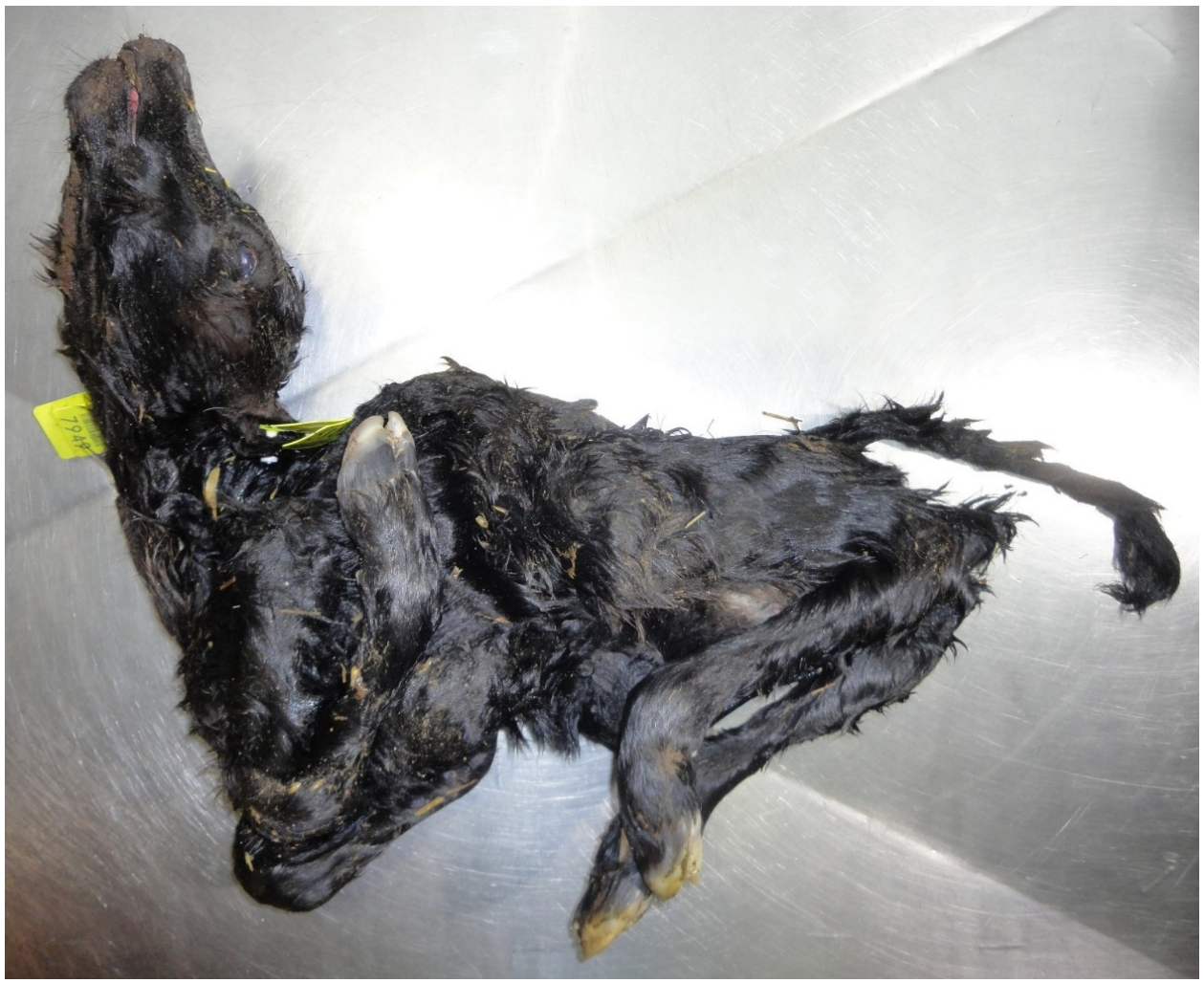

(a)

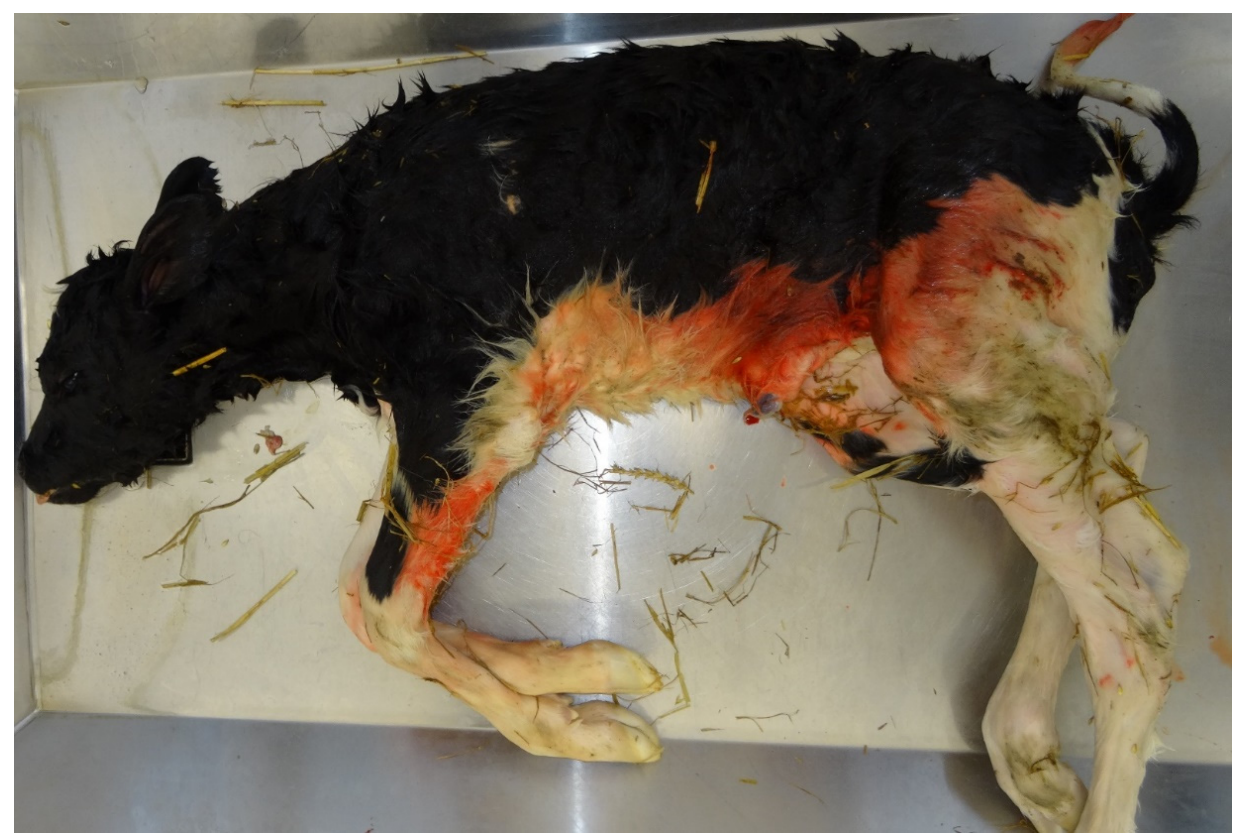

(b)

Figure 4. (a). Typical lesions of Schmallenberg infection (arthrogryposis, torticollis, kyphosis) in a bovine foetus PCR-positive for the virus. (b). Fetus exposed to Schmallenberg virus in utero and antibody-positive, but without the pathognomonic lesions.

Trueperella pyogenes

Trueperella pyogenes is not commonly detected in PM studies. Perinatal mortality, usually sporadic, due to T. pyogenes is usually secondary to a maternal suppurative focal 
infection or bacteraemia, i.e., haematogenous infection [81]. The organism can cause placentitis and foetal pneumonia, pleuritis, pericarditis and/or peritonitis, often in an autolysed foetus (Figure 5). Experimental inoculation studies have shown that T. pyogenes (Actinomyces pyogenes) is a primary pathogen in pregnant cows [81].

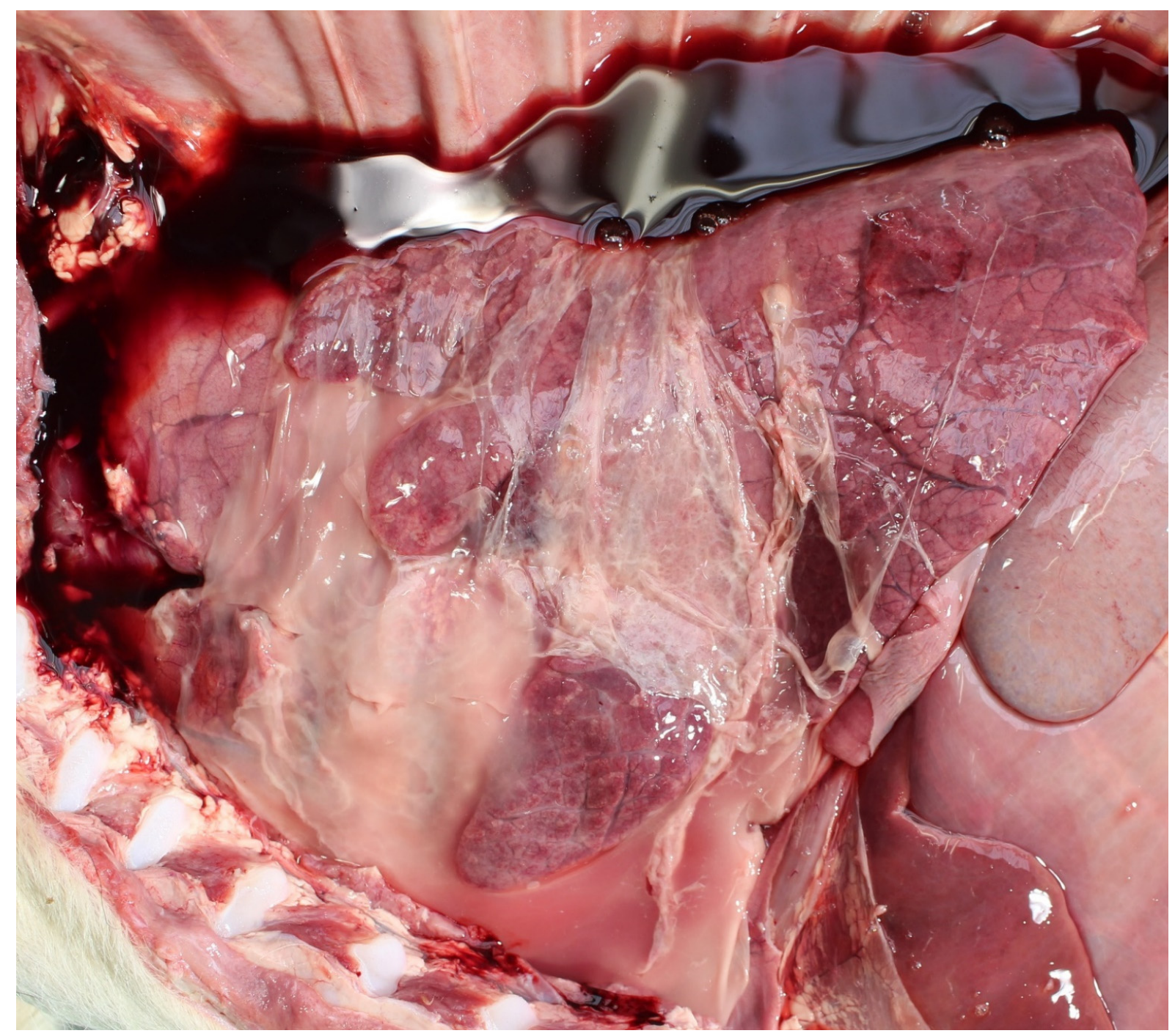

Figure 5. Extensive pleuropneumonia a foetus infected with Trueperella pyogenes.

\subsubsection{Contaminant Bacteria}

Contaminant bacteria commonly found in samples from cases of PM include coliforms, E. coli, Pseudomonas, Proteus and mixed bacterial infections [33]. Their presence indicate autolysed or contaminated sample (e.g., scavenged carcass, environmental contamination of placenta), unhygienic sample collection, sample storage at warm ambient temperature and/or undue delay between sample collection and culture [82]. Contaminant bacteria are commonly cultured from the abomasal contents of PM cases submitted to veterinary laboratories $(10-20 \%)$, but primary $(5 \%)$ and secondary bacterial pathogens $(<5 \%)$ are much less frequently isolated [10].

\subsubsection{In Utero vs. Postnatal Infection}

Perinatal losses include those occurring pre-, intra- and postpartum (variably 1-2 days after calving) periods, hence, perinates may be infected in any of these periods. Given that more perinates die during and before, than after, calving ( 25, 60,15\%, respectively [83]), in utero infections cause more PM than postnatal (0-2 days) infections. However, as a 
proportion of perinates dying in each time period (pre-, intra- and postpartum 0-2 days), more die due to infection postnatally ( $0-2$ days): $\sim 10,5$ and $15 \%$, respectively [10]. In some studies in utero infections can be the first (34\% of all diagnoses, [21] or second ( $26 \%$ of all diagnoses [14]) most common cause of PM. The types of infections also vary with time of death. Deaths which occur pre- or intra-partum attributed to infection are much more likely to be due to primary pathogens (70-75\%) while deaths which occur postpartum (0-2 days) are more likely to be due to FPT and subsequent infection from ubiquitous environmental pathogens (80-90\%) [10].

\section{Intra-Uterine Infections}

The common sources of in utero infections are vertically transmitted transplacental infections and from the animal's feed, water or environment $[8,38,60]$. Feed-borne pathogens are particularly important where feed is of poor quality, e.g., poorly fermented grass silage, more commonly in beef than in dairy herds [14] or where feed is exposed to vectors [84]. Infected foetuses may die pre-partum, during calving or postpartum (0-2 days). Common in utero infections causing PM include Neospora caninum, BVDv, Bacillus licheniformis, and Leptospira hardjo (see Table 3). In some cases of in utero infection no causative agent may be identified, particularly in foetuses which die in utero, and are autolysed. However, gross or histological specific (e.g., pericarditis, peritonitis and pneumonia) or non-specific findings (e.g., increased in utero B lymphocyte proliferation with germinal centre formation in the spleen indicating non-specific antigenic stimulation) indicate death due to infection (Figure 6) [85].

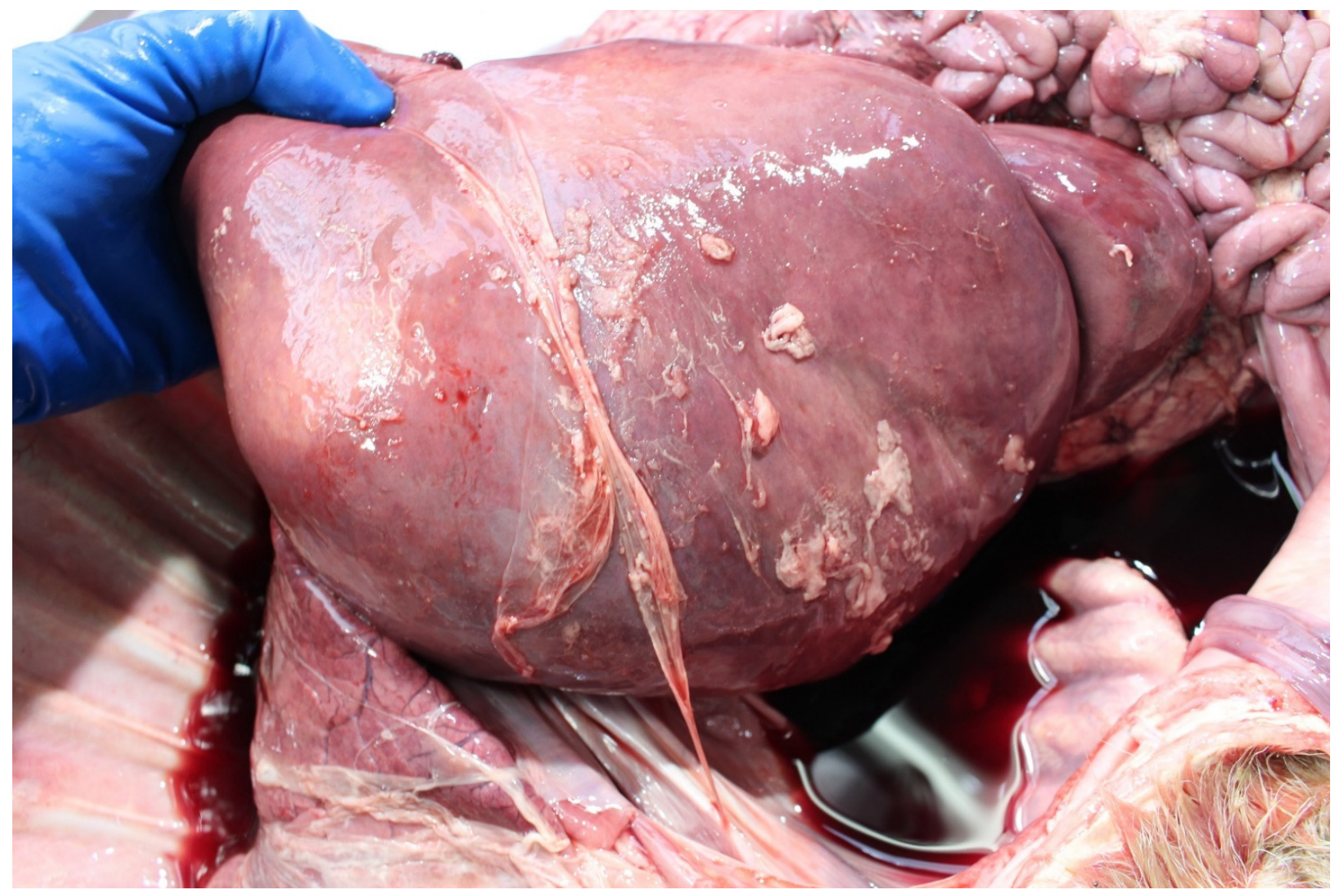

Figure 6. Peri-hepatic fibrinous peritonitis in a perinate which died in utero precalving. 


\section{Postnatal Infections}

Infection of the perinate (within two days) after birth from its new environment is normal. However, in calves with failure of passive transfer (FPT), (e.g., zinc sulphate turbidity test (ZST) result less than 12.5 units [86]) environmental infection may result in morbidity or PM [69]. Common causes include E.coli septicaemia (colisepticaemia), (e.g., [14]). Though their death may be predisposed by dystocia-induced asphyxia-associated FPT, farmers may be 'blind' to such associations or losses hence the role of postnatal infection (0-2 days) in causing PM is often underestimated [87].

\subsubsection{Exposure, Infection and Causality}

In attempting to attribute PM to infection one must differentiate between exposure to infection (foetal antibody detection), the presence of infection (antigen detected in foetal/placental tissue) without lesions and infectious causality (antigen/DNA/RNA detected in foetal tissue/abomasal contents with associated lesions or the presence of compelling inflammatory lesions indicative of infection in the absence of single foetopathogen detection, e.g., pneumonia, encephalitis, pericarditis, omphalophlebitis, peritonitis, septicaemia, hepatitis, arthritis, nephritis [11] etc, and tests exclude other diagnoses). Therefore, pathogens may be detected in the presence and/or absence of lesions and lesions may be detected in the presence and/or absence of pathogens. This point is illustrated in recent findings from the placentomes of abattoir-sourced pregnant cows in which small numbers of pathogenic bacteria were isolated without the presence of associated lesions [88]. On the contrary, where there is gross or histopathological evidence of infection or response to infection, the combined case evidence may not be compelling that the presumptive foetal infection was the cause of death as opposed to being present at death. Thus detection of exposure and/or infection must be interpreted in light of other investigative findings also.

In the absence of defence mechanisms and/or a highly virulent pathogen, intrauterine infection may result in PM. The presence of antigens without an antibody response is an indicator of infection, either very early in pregnancy (before fetal immunocompetence), or later in pregnancy when the infection kills the fetus before it seroconverts [4]. The detection of pathogens at term, which infect the fetus early in gestation, requires that the agent or its genetic material persists in the fetus, which is not always the case where there is moderatemarked in utero autolysis [13]. Therefore, the detection rate and the role of infectious agents in the aetiology of PM maybe artificially low and underestimated, respectively.

These complexities highlight the difficulties in assigning a cause of death (COD) to an infectious cause. It has been recommended that evaluation of true infectious causes should focus on both antigen detection and histological examination [21].

In contrast to the relatively limited proportion of PM attributed to infection, in bovine abortion infection is the most important diagnosed cause of death. This disparity can be obscured as many studies report findings for both abortion and PM combined (Figure 7), (e.g., $[11,12,42,89])$, and depending on the terminology used to describe the foetuses it can appear that infection is a major cause of PM. For example, a Dutch study detected pathogenic antigens in $28 \%$ of aborted and stillborn fetuses [89]. Where aborted and stillborn fetus data are disaggregated, within the same study, detection of pathogenic antigens is always significantly lower in stillborn calves. For example, at the lower end, a Canadian study diagnosed an infectious cause of death in 16\% of aborted and in only $3 \%$ of stillborn fetuses [13] while at the higher end, a Finnish study detected significant bacterial isolates in 26 and 10\% of aborted fetuses and stillborn calves, respectively [6]. These studies indicate that at term non-infectious causes of death, e.g., dystocia and asphyxia, are more important than infectious causes of death. 


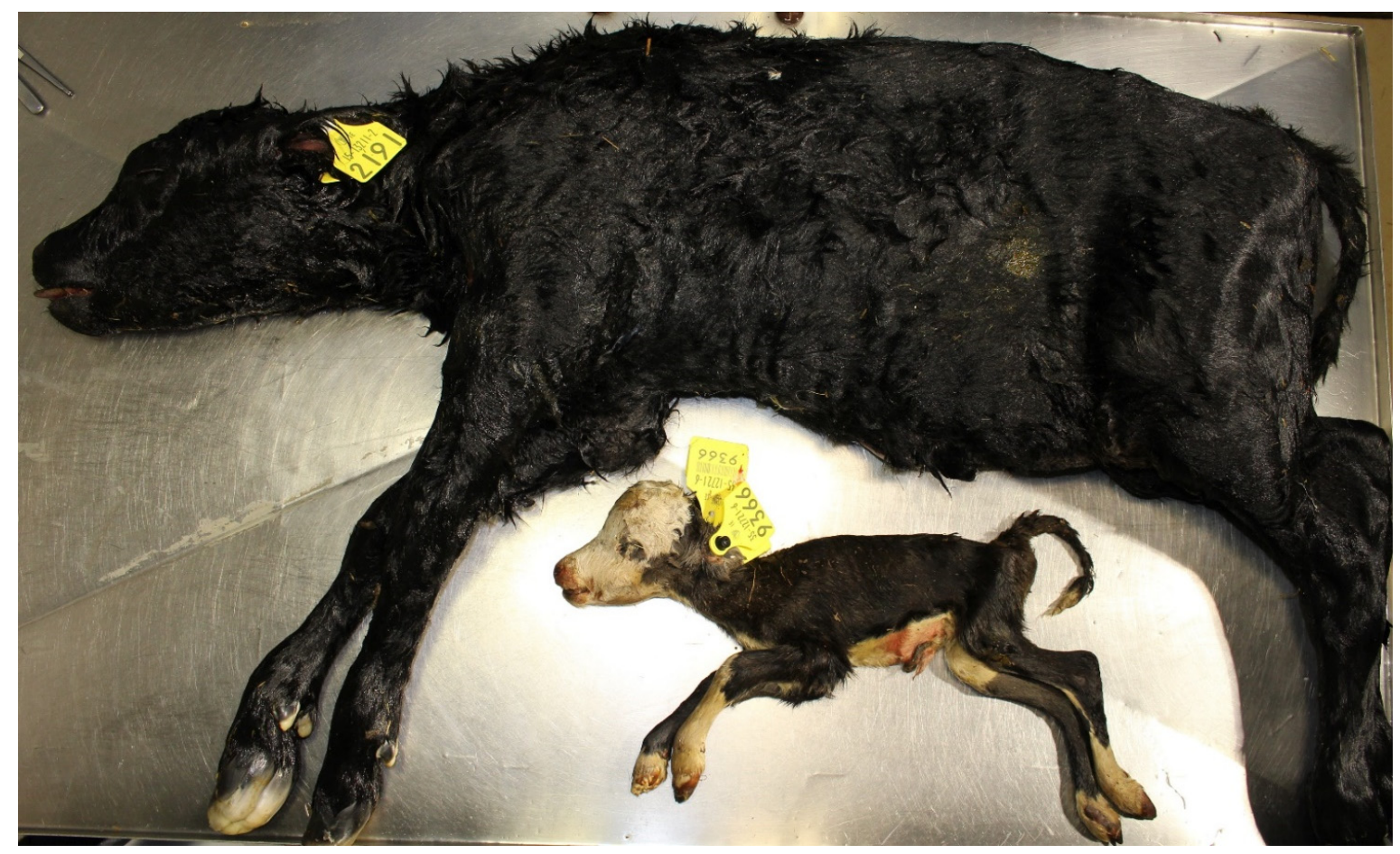

Figure 7. Aborted (2.4 kg, unknown gestation length) and stillborn (56.7 kg, $282 \mathrm{~d}$ gestation) foetuses.

\subsubsection{Proportion of Perinatal Mortality Caused by Infection}

The proportion of PM attributed to infection can vary tenfold between studies: $\sim 3$ to $35 \%$ (Table 1). Some common reasons for high variability in the attributable fraction of PM caused by infection include conflation of data from aborted and stillborn calves, geographic differences in infection prevalence and control methods (e.g., vaccination, eradication), differences in definition of 'infection', and differences in sampling protocols.

Although there are many reports investigating infection as a cause of abortion (e.g., [82]), few focus on the role of infectious agents in PM specifically and in some cases results for aborted and PM calves are combined (e.g., [89]). Unlike abortions where infections constitute the major proportion of diagnosed causes, in perinatal mortality infections are a minor diagnosed cause, generally less than $15 \%$ (with exceptions) in published studies (Table 1). However, in high mortality herds in regions where particular infections are endemic, the proportion of perinatal mortality attributable to infections may be much higher (e.g., [21]). Hence, one cannot cite data on infection rates and types in the international literature without reference to the biosecurity conditions in the country in which the data were collected. Thus, in countries free from specific infections, e.g., Brucella abortus (Poland, Republic of Ireland, Switzerland), Bovine Herpes Virus-I (BHV-I), (Sweden, Finland) or pathogenic Leptospira spp. (Sweden) $[6,20]$ ), those infectious agents will not be detected in PM calves.

Infectious foetopathy diagnostic rates in cases of PM also vary between studies depending on whether detection of exposure to infection (foetal antibody positive) or the presence of infection (antigen detected in foetal/placental tissue) with/without lesions, is the diagnostic criterion $[4,21,90]$, as discussed previously. Compelling inflammatory lesions indicative of bacterial infection (e.g., bronchopneumonia, encephalitis, pericarditis, hepatitis, omphalophlebitis and peritonitis) are often ranked as the most commonly detected criterion $[13,14,31]$. Variation in sampling protocols may also account for apparent differences in the proportion of PM cases caused by different pathogens. For example, in some studies all calves are tested, irrespective of gross pathology [4], while in others, only tissues with macroscopic pathological lesions are sampled [5]. These protocol differences 
may account for a lower infection detection rate in studies where selective sampling is implemented and a relatively higher detection rate in studies where all calves are sampled.

\section{Diagnosis of Infectious Causes of Perinatal Mortality}

The current state-of-the-art approach to investigation of all-cause perinatal mortality in calves has recently been reviewed [91]. The possible novel diagnostic approaches of the future are presented by Jawor et.al. [2] in Part 2 of this mini-series. The standard operating protocol (SOP) involves three steps: collect a history, examine the pregnant animals and the dam and examine the foetus/placenta. The focus here is on diagnosis of infectious causes only. While the criteria used to diagnose infection as a cause of PM are generally agreed, there are many caveats to the details of such attributions [1]. As with bovine abortions, the more sample material examined (i.e., foetus, and placenta and maternal blood), the higher the likelihood of an aetiological diagnosis [92].

\subsection{Herd Health History}

In the context of possible infectious causes, the herd health history is important. For example, details of most recent vaccinations against foetopathogens, recent cattle purchases, grazing cows on out-farms (e.g., alpine pastures), introducing heifers, raised on contract-rearing farms, to "home farm" before calving and (antibody/antigen) bulk milk test results.

\subsection{Cohort Sampling}

Examining the pregnant cohort and their environment allows assessment of general herd health. Cohort sampling of dams (sero-diagnosis) in the affected group can be useful in determining differences in exposure (presence/absence, prevalence) between affected and unaffected dams (case-control), but vaccinal status needs to be known [91].

\subsection{Examination of the Dam}

Clinical examination of the dam may reveal signs of infection, e.g., pyrexia, diarrhoea, respiratory signs, etc. A faecal sample may be useful where salmonellosis is suspected [91]. A single blood sample from the affected dam can have moderate utility as a proxy sample for foetal material. For example, a single blood sample from the non-vaccinated dam of a stillborn or aborted foetus can be up to $85 \%$ accurate in predicting a foetal culturepositive result for Salmonella Dublin [78]. However, the primary value of maternal serum is as an exclusionary test for maternal antibody. For example, marked rises in maternal Neospora caninum antibody titres occur during the second half of gestation associated with vertical transmission in experimental and field studies [93]. Hence, seronegative fullterm dams are unlikely to deliver a Neospora-positive foetus. However, repeat sampling may be necessary to rule out those cases whose antibody status fluctuates between seronegative and seropositive (false negatives): 'serologically elusive animals' [93]. Paired maternal sera (more than two weeks apart) may detect increased antibody values (e.g., two to four-fold titre rise, + to ++++ , or increased absorbance) for some foetopathogens (e.g., $S$. Dublin SAT) but not for others (e.g., Leptospira spp., Neospora) due to the lag phase between infection and foetal mortality $[78,91]$. Higher positive rates in maternal serology than in foetal antigen detection is not uncommon given sero-endemicity with common pathogens, e.g., Vidal et al. [25]. In vaccinated herds natural infection can still be distinguished where DIVA vaccines are used (gE-deleted BoHV-I) and where maternal titres are much higher than those expected from vaccination (e.g., Leptospira) this suggests current, active infection [91].

\subsection{Examination of the Foetus}

This examination involves three steps-external and internal examination and sampling the carcass as detailed in a recent illustrated guide to bovine foetopsy [94]. In order to avoid artefactual changes in the carcass and placenta, they should be stored in away from animal access. The external examination may detect foetal undersize (low body weight 
and/or short CRL), a possible indicator of foetal infection and shortened gestation [4]. Internal examination may reveal gross evidence of infection (which may or may not be confirmed by laboratory analyses). One of the most common lesions is pneumonia, from prenatal infection (e.g., pathogen aspiration from amniotic fluid or haematogenous spread), intranatal hypoxia (e.g., meconium aspiration possibly induced by placentitis) or postnatal (0-2 days) infection (e.g., colostrum aspiration pneumonia from misuse of an oro-gastric feeder or perinatal septicaemia) $[10,85]$. Other lesions include pericarditis, meningitis, hypopyon, intestinal rupture, DIC with haemorrhages and sepsis [91]. It is recommended that once the carcass is opened samples for microbiological testing are collected first to avoid contamination during the internal organ examination [91].

\subsubsection{Sampling the Carcass}

A sample selection algorithm for stillborn foetuses is outlined in Figure 8. It is not possible to be prescriptive about test selection as laboratories differ in the test menu and tiers they offer. Test selection will also be determined by the anamnesis, degree of carcass autolysis and costs. Rather than 'necropsy by algorithm' the decision-making of the veterinary practitioner or pathologist still determines whether and which samples to collect. Additionally, samples can be discarded if collected in the early stages of the necropsy where subsequent examination reveals the likely cause does not require laboratory testing for infectious causes [91].

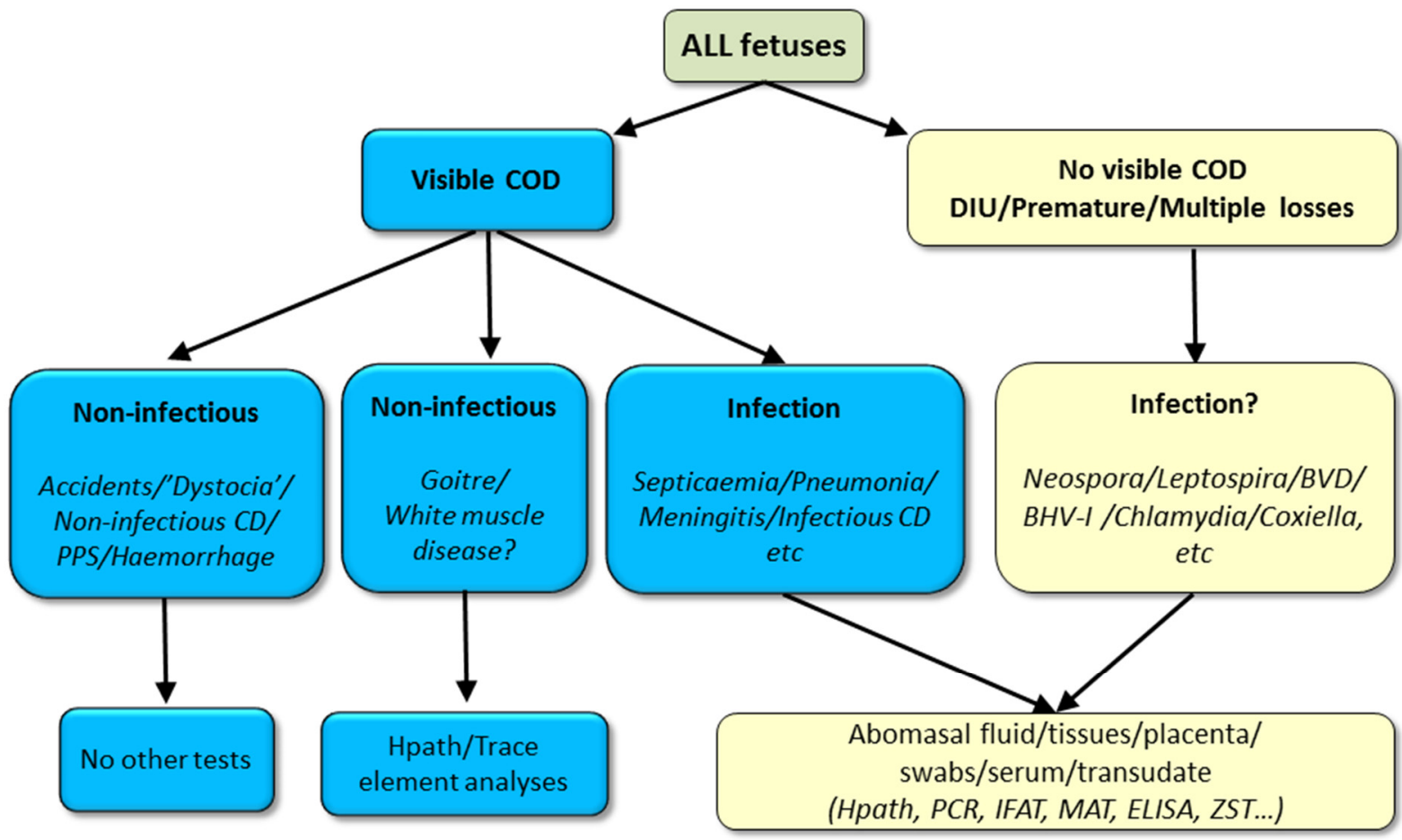

Figure 8. Necropsy sample selection decision tree for stillborn foetuses (COD = cause-of-death, CD = congenital defect, $\mathrm{DIU}=$ dead in utero). Footnote. While a non-infectious cause of death may be grossly suspected or apparent, occult infection may also be present, hence, where mandated by law or where infection is also suspected, sample/s should be collected to rule out infection, typically, abomasal contents.

\section{Microbiology Samples}

Abomasal contents (for culture, PCR and microscopy) are amongst the most important sample to collect as they represent the amniotic fluid in which the foetus lives throughout pregnancy [91]. They can be sampled aseptically by searing the abomasal serosa with a heated scalpel blade and aspirating a sample into a plain vaccutainer tube. If an abomasal sample is unobtainable (due to scavenging or colostrum ingestion) or if septicaemia is 
suspected, lung, liver or brain samples are suitable alternatives, though not as sensitive [33]. In general, tissue samples are preferable to swabbed samples and surface swabbed samples are preferable to fluid swab samples [91]. Brain sampling is of particular value in severely scavenged and mummified foetuses. The presences of a pure growth of a pathogen with associated lesions, in the absence of other causes of death, are usually accepted as diagnostic criteria.

\subsubsection{Serology Samples}

Serological sampling of the foetus can be useful from the second trimester ( $>120$ days - pathogen-dependent) when the foetus is immunocompetent as antibodies indicate foetal infection (but not necessarily foetopathy, e.g., Neopsora congenital infection), assuming placental competence [91]. However, reliance on foetal serology alone may grossly underestimate foetal infection rates [90]. The details on these and other biomarkers are discussed by Jawor et al., [2] in Part 2 of this mini-series.

\subsubsection{Histopathology Samples}

Tissues with gross lesions indicative of infection plus lung, liver, heart and brain are routinely collected for histopatholoical examination [95]. The brain is of particular value in the histopathological diagnosis of neosporosis. Samples for histopathology should include normal and adjoining abnormal tissue and should not be greater than $1 \mathrm{~cm}$ thick and $2 \mathrm{~cm}$ long as they need to fit into processing cassettes $(3.5 \times 2.5 \times 0.5 \mathrm{~cm})$ [91].

\subsubsection{Standard Microbiology Package}

Some microbiological tests are carried out routinely on all PM cases in veterinary diagnostic laboratories ('standard microbiology package') while other tests are non-routine (e.g., PCR, histopathology) [91]. While for sporadic cases the basic sampling package may suffice (Table 4), in PM outbreaks, tiered sample escalation to an extended spectrum analysis is advised as it provides the option of sampling, storing and testing as deemed necessary.

Table 4. Standard and additional samples to collect from cases of perinatal mortality * for the investigation of infectious causes of death.

\begin{tabular}{|c|c|c|c|}
\hline For Investigation of & Standard Samples & Ancillary Samples & Comments \\
\hline $\begin{array}{l}\text { Failure of passive transfer } \\
\text { of immunoglobulins }\end{array}$ & Perinate blood & $\mathrm{NA}^{* *}$ & $\begin{array}{c}\text { Only test calves }>24 \text { h old, e.g., } \\
\text { ZST test }\end{array}$ \\
\hline $\begin{array}{l}\text { Foetopathogenic bacteria and } \\
\text { fungi (e.g., Aspergillus spp., B. } \\
\text { licheniformis, L. monocytogenes, } \\
\text { T. pyogenes, S. Dublin) }\end{array}$ & $\begin{array}{c}\text { Foetal stomach contents (FSC), } \\
\text { Placenta (ideally collected } \\
\text { from dam to } \\
\text { reduce contamination) }\end{array}$ & $\begin{array}{l}\text { Foetal lung, liver, gall bladder, } \\
\text { kidney, brain, eyelid. } \\
\text { Dam vaginal swab, } \\
\text { placentome, blood. }\end{array}$ & $\begin{array}{l}\text { Ancillary samples where } \\
\text { FSC/placenta } \\
\text { unavailable/contaminated. }\end{array}$ \\
\hline Neospora caninum & Foetal brain, serum & $\begin{array}{c}\text { Foetal heart. } \\
\text { Placenta. } \\
\text { Dam/cohort bloods }\end{array}$ & $\begin{array}{c}\text { Fresh brain/placenta for PCR, } \\
\text { fixed brain or heart/placenta } \\
\text { for histopathology if } \\
\text { PCR positive }\end{array}$ \\
\hline Leptospira Hardjo & Foetal kidney, serum & Dam/cohort bloods & $\begin{array}{l}\text { Foetal sample dependent } \\
\text { upon lab. tests }\end{array}$ \\
\hline BVDv & $\begin{array}{l}\text { Foetal ear, spleen, thymus, } \\
\text { serum }\end{array}$ & $\begin{array}{l}\text { Foetal kidney. Dam/cohort } \\
\text { bloods }\end{array}$ & $\begin{array}{l}\text { Foetal sample dependent } \\
\text { upon lab. Tests }\end{array}$ \\
\hline BHV-I & Foetal liver, serum. & $\begin{array}{l}\text { Foetal kidney. Placenta. } \\
\text { Dam/cohort bloods }\end{array}$ & $\begin{array}{l}\text { Foetal PCR/histopathology } \\
\text { preferred tests }\end{array}$ \\
\hline $\begin{array}{l}\text { Gross lesions (e.g., } \\
\text { foetal pneumonia) }\end{array}$ & Affected foetal organ & As required & $\begin{array}{c}\text { As appropriate (e.g., } \\
\text { bacteriology, histopath) }\end{array}$ \\
\hline
\end{tabular}

* Standard and ancillary testing protocols are dependent upon local laboratory SOPs. Bacteriology/mycology (culture, stains, wet preparations) and serology are generally routine tests for sporadic cases while other tests (e.g., histopathology, PCR, FAT, IHC, micronutrient, DNA assay) can be added for multiple losses or at the discretion of the pathologist. Maternal vaccinal status affects use and choice of serology tests, ${ }^{* *} \mathrm{NA}-$ not applicable. 


\subsubsection{Sample Storage}

If microbiology samples are collected on a day when the veterinary laboratory is closed, e.g., weekends, holidays, the samples should be stored for culture, serology and histopathology in a fridge $\left(4^{\circ} \mathrm{C}\right)$ and those for PCR in a freezer $\left(-20^{\circ} \mathrm{C}\right)$ [91].

\subsection{Examination of the Placenta}

If the placenta has not yet been expelled at examination, a sample of the retained placentomes or a vaginal swab can be obtained [91]. A normal placenta at term weighs approximately $5 \mathrm{~kg}$, has $75-125$ red cotyledons and has thin, translucent intercotyledonary tissue that sometimes contains adventitious placentation [91]. Placentitis may be grossly manifest as discoloured, necrotic, exudative cotyledons and opaque, erythematous, thickened, oedematous intercotyledonary tissue (Figure 9) [96]. Ideally three abnormal cotyledons/inter-cotyledonary tissue samples should be submitted (preferably macroscopically abnormal and uncontaminated) for histopathological and microbiological examination (Gram smear, modified Ziel Neelsen, culture, PCR) [91]. Sampling of the placenta is of particular importance where Coxiella burnetii or Chlamydia spp. are suspected [21]. Two of the major problems with placental diagnostics is unavailability; in only a minority of cases $(<10 \%)$ of PM does the placenta accompany the foetus and environmental contamination of the temporary organ [10].

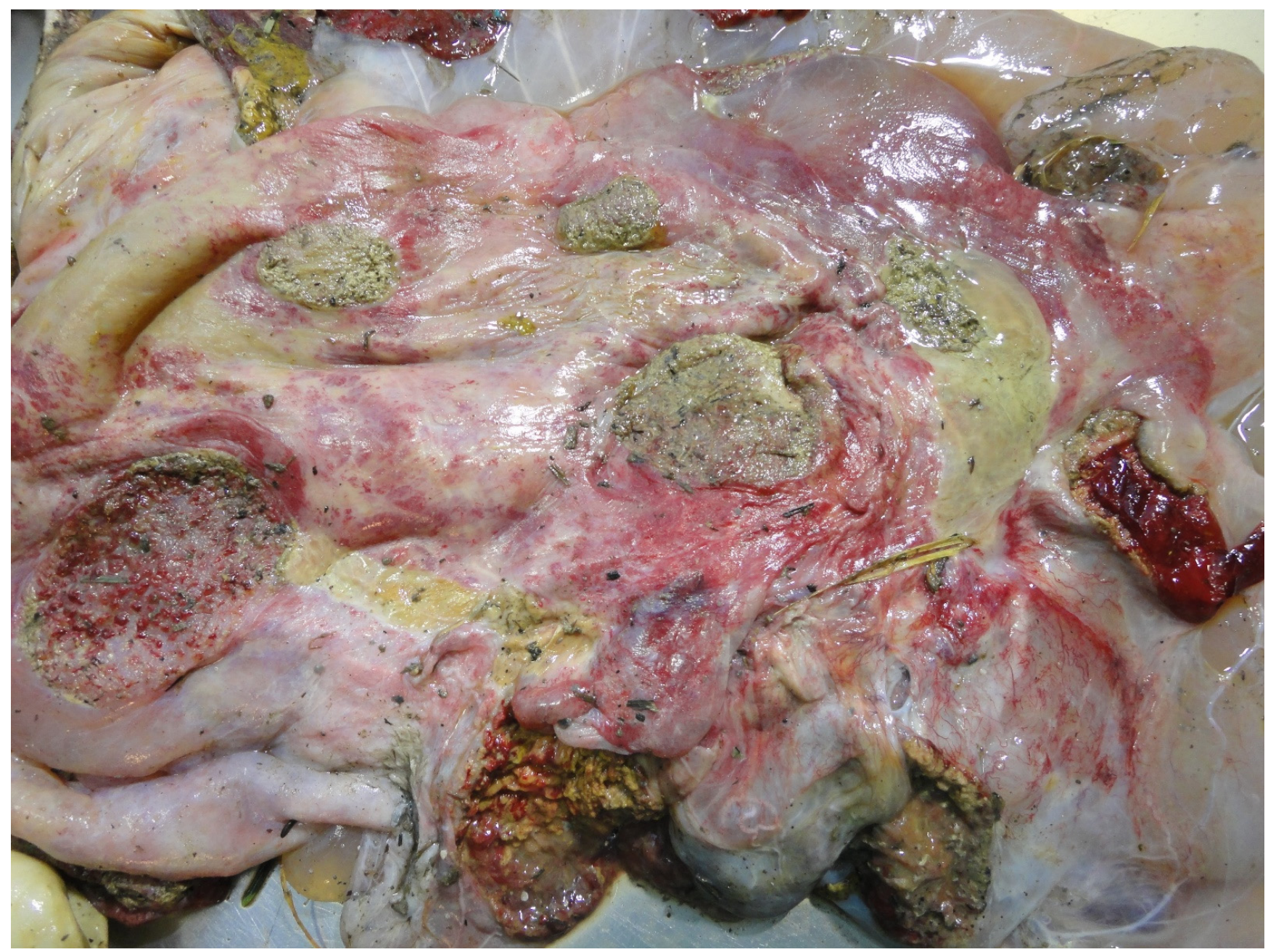

Figure 9. Severe cotyledonary and intercotyledonary placentitis. 


\section{Conclusions}

One of the most important outcomes from this review is that the diagnosis rates of infection as a cause of PM are highly variable between studies; this indicates a need for standardisation of diagnostic approaches. This review has also identified that most of the important infectious causes of PM can be controlled by management; better pregnant cow feed conservation/storage (e.g., Bacillus licheniformis), vaccination (e.g., Leptospira hardjo, BVDv) and biosecurity (e.g., Neospora caninum). While the importance of in utero infections as a cause of PM is generally recognised, the role of postnatal (0-2 days) infection, often predisposed by failure of passive transfer, can be underestimated. This differentiation is relevant to their disparate control measures. Necropsy examination is central to the current approach to diagnosis of infectious causes of PM but non-submission of the placenta often hampers a comprehensive investigation.

Author Contributions: Writing—original draft preparation, J.F.M.; writing—review and editing, J.F.M., P.J. and T.S. All authors have read and agreed to the published version of the manuscript.

Funding: This review received no external funding.

Institutional Review Board Statement: Not applicable.

Data Availability Statement: No new data were created or analyzed in this study. Data sharing is not applicable to this article.

Acknowledgments: The authors thank national and international collaborators, students and farmers who contributed to the research reviewed here and the funding bodies which grant-aided such work.

Conflicts of Interest: The authors declare no conflict of interest.

\section{References}

1. Mee, J.F. Why Do So Many Calves Die on Modern Dairy Farms and What Can We Do about Calf Welfare in the Future? Animals 2013, 3, 1036-1057. [CrossRef] [PubMed]

2. Jawor, P.; Mee, J.F.; Stefaniak, T. Role of Infection and Immunity in Bovine Perinatal Mortality: Part 2. Foetomaternal response to infection and novel diagnostic perspectives. unpublished, manuscript in preparation.

3. Murray, R. Developing an evidence-based diagnostic approach for perinatal mortality in cattle. Hung. Vet. J. 2008, 130, 86-90.

4. Jawor, P.; Król, D.; Mee, J.F.; Sołtysiak, Z.; Dzimira, S.; Larska, M.; Stefaniak, T. Infection exposure, detection and causes of death in perinatal mortalities in Polish dairy herds. Theriogenology 2017, 103. [CrossRef] [PubMed]

5. Agerholm, J.S.; Basse, A.; Krogh, H.V.; Christensen, K.; Rønsholt, L. Abortion and calf mortality in Danish cattle herds. Acta Vet. Scand. 1993, 34, 371-377. [CrossRef]

6. Syrjälä, P.; Anttila, M.; Dillard, K.; Fossi, M.; Collin, K.; Nylund, M.; Autio, T. Causes of bovine abortion, stillbirth and neonatal death in Finland 1999-2006. Acta Vet. Scand. 2007, 49, S3. [CrossRef]

7. Doherty, M. Serious perinatal mortality in cattle associated with bovine virus diarrhoea-mucosal disease (BVD-MD) virus. lrish Vet. J. 1986, 40, 189-190.

8. Collins, Á.B.; Doherty, M.L.; Barrett, D.J.; Mee, J.F. Schmallenberg virus: A systematic international literature review (2011-2019) from an Irish perspective. Ir. Vet. J. 2019, 72. [CrossRef]

9. Fernandez, M.; Campero, C. Pérdidas reproductivas en bovinos causadas por abortos, muertes prematuras, natimortos y neonatos: casuística del período 2006-2007. Rev. Med. 2007, 246-254.

10. Mee, J.F.; Teagasc, Cork, Ireland. Personal Communication, 2020.

11. Kirkbride, C.A. Viral agents and associated lesions detected in a 10-year study of bovine abortions and stillbirths. J. Vet. Diagnostic Investig. 1992, 4, 374-379. [CrossRef]

12. Khodakaram-Tafti, A.; Ikede, B.O. A retrospective study of sporadic bovine abortions, stillbirths, and neonatal abnormalities in Atlantic Canada, from 1990 to 2001. Can. Vet. J. 2005, 46, 635-637.

13. Waldner, C.L.; Kennedy, R.I.; Rosengren, L.B.; Pollock, C.M.; Clark, E.G. Gross postmortem and histologic examination findings from abortion losses and calf mortalities in western Canadian beef herds. Can. Vet. J. 2010, 51, 1227-1238. [PubMed]

14. Norquay, R.; Orr, J.; Norquay, B.; Ellis, K.A.; Mee, J.F.; Reeves, A.; Scholes, S.; Geraghty, T. Perinatal mortality in 23 beef herds in Orkney: Incidence, risk factors and aetiology. Vet. Rec. 2020, 187, 28. [CrossRef] [PubMed]

15. de Kruif, A.; Benedictus, G. Perinatale sterfte en de geboorte van weinig levenskrachtige kalveren. Tijdschr. Diergeneeskd. 1993, 118, 684-688. [PubMed]

16. Siguroarson, S.; Vioarsson, H.; Jonsson, M. Orsakir kalfadauoa um buro hja fyrsta kalfs kvigum. Orsakir kalfadauoa hja fyrsta kalfs kvigum. Syyrsla um rannosoknir 2006-2008, Landbunaoarhaaskoll Islands. Rit Lbhl 2008, 19, 34-42. 
17. Ogata, Y.; Nakao, T.; Takahashi, K.; Abe, H.; Misawa, T.; Urushiyama, Y.; Sakai, J. Intrauterine Growth Retardation as a Cause of Perinatal Mortality in Japanese Black Beef Calves. J. Vet. Med. Ser. A Physiol. Pathol. Clin. Med. 1999, 46, 327-334. [CrossRef]

18. Muskens, J.; Vos, J. Post mortem examinations of aborted and stillborn calves. Reprod. Dom. Anim. 2008, 43 (Suppl. S5), 107.

19. McCoy, M.; Smyth, J.; Ellis, W.; Kennedy, D. Stillbirth/Perinatal weak calf syndrome. Cattle Pract. 1997, 5, 31-34.

20. Berglund, B.; Steinbock, L.; Elvander, M. Causes of stillbirth and time of death in Swedish Holstein calves examined post mortem. Acta Vet. Scand. 2003, 44, 111-120. [CrossRef]

21. Mock, T.; Mee, J.F.; Dettwiler, M.; Rodriguez-Campos, S.; Hüsler, J.; Michel, B.; Häfliger, I.M.; Drögemüller, C.; Bodmer, M.; Hirsbrunner, G. Evaluation of an investigative model in dairy herds with high calf perinatal mortality rates in Switzerland: Perinatal mortality on high risk dairy farms in Switzerland. Theriogenology 2020, 148, 48-59. [CrossRef]

22. Schefers, J. Why stillborns are still born. Hoard's Dairym. 2009, 154, 10.

23. Smyth, J.A.; McNamee, P.T.; Kennedy, D.G.; McCullough, S.J.; Logan, E.F.; Ellis, W.A. Stillbirth/perinatal weak calf syndrome: preliminary pathological, microbiological and biochemical findings. Vet. Rec. 1992, 130, 237-240. [CrossRef] [PubMed]

24. Zanatto, D.C.S.; Gatto, I.R.H.; Labruna, M.B.; Jusi, M.M.G.; Samara, S.I.; Machado, R.Z.; André, M.R. Coxiella burnetii associated with BVDV (Bovine Viral Diarrhea Virus), BoHV (bovine herpesvirus), Leptospira spp., Neospora caninum, Toxoplasma gondii and trypanosoma vivax in reproductive disorders in cattle. Rev. Bras. Parasitol. Vet. 2019, 28, 245-257. [CrossRef]

25. Vidal, S.; Kegler, K.; Greub, G.; Aeby, S.; Borel, N.; Dagleish, M.P.; Posthaus, H.; Perreten, V.; Rodriguez-Campos, S. Neglected zoonotic agents in cattle abortion: Tackling the difficult to grow bacteria. BMC Vet. Res. 2017, 13. [CrossRef] [PubMed]

26. Agerholm, J.S.; Krogh, H.V.; Jensen, H.E. A Retrospective Study of Bovine Abortions Associated with Bacillus licheniformis. J. Vet. Med. Ser. B 1995, 42, 225-234. [CrossRef]

27. Jawor, P.; Stefaniak, T.; Sołtysiak, Z.; Dzimira, S.; Bednarski, M. Salmonella enterica serovar Stanley intrauterine infection in a stillborn calf - case report. Acta Vet. Brno 2013, 82, 363-367. [CrossRef]

28. Serrano-Pérez, B.; Almería, S.; Mur, R.; Alabart, J.L.; López-Helguera, I.; Garcia-Ispierto, I.; López-Gatius, F. Caracterización de las citoquinas involucradas en la luteolisis del cuerpo luteo de vacas abortadas por la infección experimental con Neospora caninum. In Proceedings of the XVII Jornadas Sobre Producción Animal, Zaragoza, Spain, 30-31 May 2017; pp. 752-754.

29. Di Blasio, A.; Traversa, A.; Giacometti, F.; Chiesa, F.; Piva, S.; Decastelli, L.; Dondo, A.; Gallina, S.; Zoppi, S. Isolation of Arcobacter species and other neglected opportunistic agents from aborted bovine and caprine fetuses. BMC Vet. Res. 2019, 15, 257. [CrossRef]

30. Hassig, M. Fetal antibodies against the placenta in miscarriages in cattle. Reprod. Domest. Anim. 1990, 25, 139-140.

31. Anderson, M.L. Infectious causes of bovine abortion during mid- to late-gestation. Theriogenology 2007, 68, 474-486. [CrossRef] [PubMed]

32. Sanchez-Miguel, C. Bovine abortion, All-Island Animal Disease Surveillance Report 2019; Department of Agriculture, Food and the Marine: Dublin, Ireland, 2020.

33. Clothier, K.; Anderson, M. Evaluation of bovine abortion cases and tissue suitability for identification of infectious agents in California diagnostic laboratory cases from 2007 to 2012. Theriogenology 2016, 85, 933-938. [CrossRef] [PubMed]

34. Mee, J.F. Bovine abortion. In Bovine Prenatal, Perinatal and Neonatal Medicine; Szenci, O., Mee, J.F., Bleul, U., Taverne, M.A.M., Eds.; Hungarian Association for Buiatrics: Budapest, Hungary, 2021.

35. Wheelhouse, N.; Liverpool University, Liverpool, UK. Diplome in Bovine Reproduction. Personal Communication, 2018.

36. Wheelhouse, N.; Liverpool University, Liverpool, UK. Diplome in Bovine Reproduction. Personal Communication, 2020.

37. Murray, R.D.; Williams, A.J.; Sheldon, I.M. Field investigation of perinatal mortality in Friesian cattle associated with myocardial degeneration and necrosis. Reprod. Domest. Anim. 2008, 43, 339-345. [CrossRef]

38. Otter, A. Cattle abortions update. Vet. Rec. 2020, 186, 597-598. [CrossRef]

39. Scottish Agriculture Colleges (SAC) Surveillance report Reproductive tract conditions. Vet. Rec. 2017, 181, 31.

40. Johnston, W.; MacLachlan, G.; Hopkins, G. An outbreak of sudden death and respiratory disease in weaned calves due to Bacillus Licheniformis infection and subsequent abortions and stillbirths. In Proceedings of the 3rd International Symposium World Association Veterinary Laboratory Diagnosticians, Ames, IA, USA, 13-15 June 1983; pp. 107-110.

41. Benedictus, G. Perinatale kalversterfte met symptomen van het “weak calf syndrome”. Tijdschr. Diergeneeskd. 1989, 114, 1046-1048.

42. Graham, D.A.; Beggs, N.; Mawhinney, K.; Calvert, V.; Cunningham, B.; Rowan-Layberry, L.; McLaren, I. Comparative evaluation of diagnostic techniques for bovine viral diarrhoea virus in aborted and stillborn fetuses. Vet. Rec. 2009, 164, 56-58. [CrossRef]

43. Schefers, J.; Munoz-Zanzi, C.; Collins, J.E.; Goyal, S.M.; Ames, T.R. Serological evaluation of precolostral serum samples to detect Bovine viral diarrhea virus infections in large commercial dairy herds. J. Vet. Diagnostic Investig. 2008, 20, 625-628. [CrossRef] [PubMed]

44. Grooms, D.L. Reproductive consequences of infection with bovine viral diarrhea virus. Vet. Clin. North Am. Food Anim. Pract. 2004, 20, 5-19. [CrossRef] [PubMed]

45. Smyth, J.A.; Fitzpatrick, D.A.; Ellis, W.A. Stillbirth/perinatal weak calf syndrome: a study of calves infected with Leptospira. Vet. Rec. 1999, 145, 539-542. [CrossRef] [PubMed]

46. Ellis, W.A.; O’Brien, J.J.; Neill, S.D.; Bryson, D.G. Bovine leptospirosis: Experimental serovar hardjo infection. Vet. Microbiol. 1986, 11, 293-299. [CrossRef]

47. Delooz, L.; Czaplicki, G.; Gregoire, F.; Dal Pozzo, F.; Pez, F.; Kodjo, A.; Saegerman, C. Serogroups and genotypes of Leptospira spp. strains from bovine aborted foetuses. Transbound. Emerg. Dis. 2018, 65, 158-165. [CrossRef] [PubMed] 
48. Bartley, P.M.; Guido, S.; Mason, C.; Stevenson, H.; Chianini, F.; Carty, H.; Innes, E.A.; Katzer, F. Detection of Neospora caninum DNA in cases of bovine and ovine abortion in the South-West of Scotland. Parasitology 2019, 146, 979-982. [CrossRef]

49. Brickell, J.S.; McGowan, M.M.; Wathes, D.C. Association between Neospora caninum seropositivity and perinatal mortality in dairy heifers at first calving. Vet. Rec. 2010, 167, 82-85. [CrossRef] [PubMed]

50. Thurmond, M.C.; Hietala, S.K.; Claudia Muiioz-Zanzi, C. Stillbirths Associated with Neospora caninum and BVDV type II in Dairy Heifers. In Proceedings of the American Association of Bovine Practitioners Proceedings of the Annual Conference, Vancouver, BC, Canada, 13-15 September 2001; p. 154.

51. Graham, D.A.; Smyth, J.A.; McLaren, I.E.; Ellis, W.A. Stillbirth/perinatal weak calf syndrome: serological examination for evidence of Neospora caninum infection. Vet. Rec. 1996, 139, 523-524. [CrossRef] [PubMed]

52. Innes, E.A.; Andrianarivo, A.G.; Björkman, C.; Williams, D.J.L.; Conrad, P.A. Immune responses to Neospora caninum and prospects for vaccination. Trends Parasitol. 2002, 18, 497-504. [CrossRef]

53. Buxton, D.; McAllister, M.M.; Dubey, J.P. The comparative pathogenesis of neosporosis. Trends Parasitol. 2002, 18, 546-552. [CrossRef]

54. Pospíšil, Z.; Krejčí, J.; Machatková, M.; Zendulková, D.; Lány, P.; Číhal, P. The efficacy of an inactivated IBR vaccine in the prevention of intra-uterine infection and its use in a disease-control programme. J. Vet. Med. Ser. B 1996, 43, 15-21. [CrossRef]

55. Egyed, L.; Sassi, G.; Tibold, J.; Mádl, I.; Szenci, O. Symptomless intrauterine transmission of bovine herpesvirus 4 to bovine fetuses. Microb. Pathog. 2011, 50, 322-325. [CrossRef]

56. Smith, M.W.; Miller, R.B.; Svoboda, I.; Lawson, K.F. Efficacy of an intranasal infectious bovine rhinotracheitis vaccine for the prevention of abortion in cattle. Can. Vet. J. 1978, 19, 63-71.

57. Wilson, T.E. Observations and comments on two outbreaks of abortion associated with IBR virus infection. Can. Vet. J. La Rev. Vet. Can. 1974, 15, 227-229.

58. Flammini, C.; Allegri, G. Osservazioni su un focolaio di aborto da virus IBR nella bovina. Nuova Vet. 1972, $48,224$.

59. Miller, R.B.; Smith, M.W.; Lawson, K.F. Some lesions observed in calves born to cows exposed to the virus of infectious bovine rhinotracheitis in the last trimester of gestation. Can. J. Comp. Med. Rev. Can. Médecine Comparée 1978, 42, 438-445.

60. Wheelhouse, N.; Mearns, R.; Willoughby, K.; Wright, E.; Turnbull, D.; Longbottom, D. Evidence of members of the Chlamydiales in bovine abortions in England and Wales. Vet. Rec. 2015, 176, 465. [CrossRef] [PubMed]

61. Wheelhouse, N.; Flockhart, A.; Aitchison, K.; Livingstone, M.; Finlayson, J.; Flachon, V.; Sellal, E.; Dagleish, M.P.; Longbottom, D. Experimental challenge of pregnant cattle with the putative abortifacient Waddlia chondrophila. Sci. Rep. 2016, 6. [CrossRef]

62. Borel, N.; Ruhl, S.; Casson, N.; Kaiser, C.; Pospischil, A.; Greub, G. Parachlamydia spp. and related Chlamydia-like organisms and bovine abortion. Emerg. Infect. Dis. 2007, 13, 1904-1907. [CrossRef] [PubMed]

63. Barkallah, M.; Gharbi, Y.; Hassena, A.B.; Slima, A.B.; Mallek, Z.; Gautier, M.; Greub, G.; Gdoura, R.; Fendri, I. Survey of infectious etiologies of bovine abortion during mid- to late gestation in dairy herds. PLoS ONE 2014, 9, e91549. [CrossRef] [PubMed]

64. Anonymous. Chlamydophila abortus. Vet. Irel. J. 2013, 3, 262.

65. Nielsen, K.T.; Nielsen, S.S.; Agger, J.F.; Christoffersen, A.B.; Agerholm, J.S. Association between antibodies to Coxiella burnetii in bulk tank milk and perinatal mortality of Danish dairy calves. Acta Vet. Scand. 2011, 53, 1-8. [CrossRef]

66. Seo, M.G.; Ouh, I.O.; Kwak, D. Herd prevalence and genotypes of Coxiella burnetii in dairy cattle bulk tank milk in Gyeongsang provinces of South Korea. Trop. Anim. Health Prod. 2018, 50, 1399-1404. [CrossRef]

67. Ryan, E.D.; Kirby, M.; Collins, D.M.; Sayers, R.; Mee, J.F.; Clegg, T. Prevalence of Coxiella burnetii (Q fever) antibodies in bovine serum and bulk-milk samples. Epidemiol. Infect. 2011, 139, 1413-1417. [CrossRef]

68. Freick, M.; Konrath, A.; Enbergs, H.; Walraph, J.; Weber, J.; Eulenberger, K. Detection of Coxiella burnetii DNA and anti-Coxiella burnetii IgG antibodies in precolostral blood samples of stillborn calves in an endemically infected Holstein dairy herd. Folia Microbiol. 2018, 63, 253-260. [CrossRef]

69. Fecteau, G.; Smith, B.P.; George, L.W. Septicemia and Meningitis in the Newborn Calf. Vet. Clin. North Am. Food Anim. Pract. 2009, 25, 195-208. [CrossRef]

70. Knudtson, W.U.; Kirkbride, C.A. Fungi associated with bovine abortion in the northern plains states (USA). J. Vet. Diagnostic Investig. 1992, 4, 181-185. [CrossRef] [PubMed]

71. Whitman, K.J.; Bono, J.L.; Clawson, M.L.; Loy, J.D.; Bosilevac, J.M.; Arthur, T.M.; Ondrak, J.D. Genomic-based identification of environmental and clinical Listeria monocytogenes strains associated with an abortion outbreak in beef heifers. BMC Vet. Res. 2020, 16. [CrossRef] [PubMed]

72. Szacawa, E.; Jawor, P.; Dudek, K.; Bednarek, D.; Stefaniak, T. Screening for Mollicutes microorganisms in perinatal calf mortality cases in Polish dairy herds. Pol. J. Vet. Sci. 2018, 21, 441-444. [CrossRef]

73. Trichard, C.J.; Jacobsz, E.P. Mycoplasmas recovered from bovine genitalia, aborted foetuses and placentas in the Republic of South Africa. Onderstepoort J. Vet. Res. 1985, 52, 105-110. [PubMed]

74. Ball, H.J.; Neill, S.D.; Ellis, W.A.; O'Brien, J.J.; Ferguson, H.W. The isolation of mycoplasma from bovine foetuses and their dams. Br. Vet. J. 1978, 134, 584-589. [CrossRef]

75. Langford, E.V. Mycoplasma recovered from bovine male and female genitalia and aborted foeti. Proc. Am. Assoc. Vet. Lab. Diagn. 1976, 19, 221-232.

76. Bocklisch, H.; Pfützner, H.; Martin, J.; Templin, G.; Kreusel, S. Mycoplasma-bovis-Aborte bei Kühen nach experimenteller Infektion. Arch. Exp. Veterinarmed. 1986, 40, 48-55. 
77. Stalheim, O.H.; Proctor, S.J. Experimentally induced bovine abortion with Mycoplasma agalactiae subsp bovis. Am. J. Vet. Res. 1976, 37, 879-883.

78. Sánchez-Miguel, C.; Crilly, J.; Grant, J.; Mee, J.F. Sensitivity, specificity and predictive probability values of serum agglutination test titres for the diagnosis of Salmonella Dublin culture-positive bovine abortion and stillbirth. Transbound. Emerg. Dis. 2017. [CrossRef]

79. Nielsen, T.D.; Nielsen, L.R.; Toft, N.; Houe, H. Association between bulk-tank milk Salmonella antibody level and high calf mortality in Danish dairy herds. J. Dairy Sci. 2010, 93, 304-310. [CrossRef]

80. Wernike, K.; Holsteg, M.; Schirrmeier, H.; Hoffmann, B.; Beer, M. Natural infection of pregnant cows with Schmallenberg virus-A follow-up study. PLoS ONE 2014, 9, e98223. [CrossRef]

81. Semambo, D.K.; Ayliffe, T.R.; Boyd, J.S.; Taylor, D.J. Early abortion in cattle induced by experimental intrauterine infection with pure cultures of Actinomyces pyogenes. Vet. Rec. 1991, 129, 12-16. [CrossRef]

82. Wolf-Jäckel, G.A.; Hansen, M.S.; Larsen, G.; Holm, E.; Agerholm, J.S.; Jensen, T.K. Diagnostic studies of abortion in Danish cattle 2015-2017. Acta Vet. Scand. 2020, 62. [CrossRef] [PubMed]

83. Mee, J.F. Economic and welfare consequence of perinatal mortality in dairy calves. In Bovine Prenatal, Perinatal and Neonatal Medicine; Szenci, O., Mee, J.F., Bleul, U., Taverne, M.A.M., Eds.; Hungarian Association for Buiatrics: Budapest, Hungary, 2021; in press.

84. Fávero, J.F.; de Araújo, H.L.; Lilenbaum, W.; Machado, G.; Tonin, A.A.; Baldissera, M.D.; Stefani, L.M.; Da Silva, A.S. Bovine leptospirosis: Prevalence, associated risk factors for infection and their cause-effect relation. Microb. Pathog. 2017, 107, 149-154. [CrossRef] [PubMed]

85. Norquay, R. Perinatal Losses in Beef Herds in Orkney: Assessing Incidence and Associated Pathology from General Practice. MVM Thesis, University of Glasgow, Glasgow, UK, 2017.

86. Hogan, I.; Crowe, B.; Doherty, M.; Fagan, J.; Kennedy, E.; Conneely, M.; Lorenz, I. Optimisation of the zinc sulphate turbidity test for the determination of immune status. Vet. Rec. 2016, 178, 169. [CrossRef] [PubMed]

87. Mee, J.F. Denormalizing poor dairy youngstock management: dealing with "farm-blindness". J. Anim. Sci. 2020, 98, S140-S149. [CrossRef] [PubMed]

88. Karstrup, C.C.; Klitgaard, K.; Jensen, T.K.; Agerholm, J.S.; Pedersen, H.G. Presence of bacteria in the endometrium and placentomes of pregnant cows. Theriogenology 2017, 99, 41-47. [CrossRef]

89. Muskens, J.; Wouda, W.; von Bannisseht-Wijsmuller, T.; van Maanen, C. Prevalence of Coxiella burnetii infections in aborted fetuses and stillborn calves. Vet. Rec. 2012, 170, 260. [CrossRef]

90. Mee, J.F.; Sanchez-Miguel, C.; Nosov, M.; Gilmore, J. Are we misdiagnosing many Neospora and Leptospira-positive bovine aborted and stillborn fetuses using fetal serology? (Abstract). Reprod. Domest. Anim. 2016, 51, 116.

91. Mee, J.F. Investigation of bovine abortion and stillbirth/perinatal mortality-Similar diagnostic challenges, different approaches. Ir. Vet. J. 2020, 73, 1-13. [CrossRef]

92. Jamaluddin, A.A.; Case, J.T.; Hird, D.W.; Blanchard, P.C.; Peauroi, J.R.; Anderson, M.L. Dairy cattle abortion in California: Evaluation of diagnostic laboratory data. J. Vet. Diagnostic Investig. 1996, 8, 210-218. [CrossRef] [PubMed]

93. Guido, S.; Katzer, F.; Nanjiani, I.; Milne, E.; Innes, E.A. Serology-Based Diagnostics for the Control of Bovine Neosporosis. Trends Parasitol. 2016, 32, 131-143. [CrossRef]

94. Mee, J.F. A practitioner's guide to post-mortem examination of an aborted or stillborn calf. Livestock 2016, 21, 38-43. [CrossRef]

95. Geraghty, T.; Murphy, A.; Mee, J.F.; Orr, J. How to investigate a stillbirth on farm. In Pract. 2021, in press.

96. Mee, J.F.; Ley, R. How to set up a postmortem facility in a farm animal practice. UK Vet Livest. 2021, in press. 